\title{
Teos Antik Yerleşimi Çevresinde Paleocoğrafya-Jeoarkeoloji Araştırmalarının İlk Sonuçları (Seferihisar-İzmir)
}

\section{Preliminary Results of Paleocographical-Geoarcheological Research Around the Teos Ancient Settlement (Seferihisar-İzmir)}

\author{
Serdar VARDAR ${ }^{1} \oplus$, Rufat ILLHAN $^{2} \odot$, Ertuğ ÖNER ${ }^{3} \odot$ \\ 'İzmir Kâtip Çelebi Üniversitesi, Edebiyat Fakültesi, Coğrafya Bölümü, İzmir, Türkiye \\ ${ }^{2}$ Adıyaman Üniversitesi, Edebiyat Fakültesi, Arkeoloji Bölümü, Adıyaman, Türkiye \\ ${ }^{3}$ Ege Üniversitesi, Edebiyat Fakültesi, Coğrafya Bölümü, İzmir, Türkiye
}

ORCID: S.V. 0000-0002-8448-9290; R.İ. 0000-0001-8392-9349; E.Ö. 0000-0002-9712-5277

\section{öz}

Bu araştırma Teos antik kenti çevresinde Holosen boyunca meydana gelen kıyı çizgisi ve doğal çevre değişmelerinin belirlenmesi amacıyla yapılmıştır. Antik kentin çevresinin paleocoğrafya koşullarının ve bunun jeoarkeolojik sonuçlarının belirlenmesinde alüvyon delgi sondaj yöntemi kullanılmıştır. Teos antik kenti kıyıya paralel uzanan K-G doğrultulu Ekmeksiz tepe sırtının doğu güneydoğu yamacı ile etekleri boyunca geniş bir alana yayılmıştır. Yapılan 11 delgi sondaj kentin doğusundaki Çayırarası kıyı ovasında K-G ve B-D doğrultulu iki hat üzerinde yapılmıştır. Paleocoğrafya ve jeoarkeoloji değerlendirmeleri sondaj örneklerinin sedimantolojik, element ve mikropaleontolojik analizleri yapıldıktan sonra elde edilen verilere dayanarak yapılmıştır. Elde edilen ilk bulgulara göre Çayırarası kıyı ovası dolgularının katmanlarının en alttan en üste doğru; denizel ortam sedimanları, kıyı bataklığı ortamı, Çayırarası taşkın ovası ve Teos kültür dolgularından meydana geldiği belirlenmiştir. Teos-2019-01 sondajından yapılan C14 tarihlemesi GÖ 3320 (Calibrated) yılını vermiştir. Buna göre, Çayırarası ovasının bulunduğu depresyonun Orta Holosen'de (Nortgripiyen) (Erken Tunç Çağı) K-G doğrultusunda uzanan boğaz şeklinde bir deniz ve Teos antik kentinin üzerinde bulunduğu Ekmeksiz tepenin bir ada olduğu saptanmıştır (GÖ 7000-6000). Teos antik kenti ve limanının Çayırarası depresyonuna uzanan kesiminin Tunç Çağı'ndan günümüze Yassıçayın taşkınları ve yamaç selleri ile örtüldüğü belirlenmiştir.

Anahtar kelimeler: Teos, Paleocoğrafya, Jeoarkeoloji

\section{ABSTRACT}

This research was carried out to determine the changes to the coastline and to the natural environment that occurred during the Holocene Epoch around the ancient city of Teos. Alluvial core drilling method was used to determine the paleogeographic conditions of the ancient city and its geoarchaeological results. 11 core drillings were carried out on two lines in the K-G and B-D direction on the coastal plain of Çayırarası in the east of the city. The paleogeography and geoarchaeology evaluations were made based on the data obtained after the sedimentological, element and micropaleontological analyzes of the drilling samples. According to the first results, the layers of the coastal plain fillings of Çayırarası are marine sediments, coastal swamp environment, Çayırarası flood plain and Teos culture fillings. C14 dating from Teos-2019-01 drilling determined the year to be 3320 BP(Calibrated). Accordingly, it was found that the depression in the Çayırarası plain was a strait-like sea extending towards the K-G direction in the Middle Holocene and that the Ekmeksiz hill where the ancient city of Teos was located was an island. Our findings determined that the section of Teos antique city and harbor extending towards the Çayırarası depression had been covered with floods of Yassıçay and slope floods since the Bronze Age.

Keywords: Teos, Paleogeography, Geoarchaeology

Başvuru/Submitted: 29.02.2020 • Revizyon Talebi/Revision Requested: 03.04.2020 • Son Revizyon/Last Revision Received: 28.05 .2020 - Kabul/Accepted: 31.05.2020 - Online Yayın/Published Online: 23.06 .2020 


\section{EXTENDED ABSTRACT}

Natural environment changes occurring on the coasts of Western Anatolia during the Holocene Epoch have influenced the settlements that existed here from prehistory to the present. Changes in the sea level with the last glacier resulted in the change of the natural environment of the coastline and the surrounding coastal plains. Teos, located on the Aegean coast, is one of the ancient coastal settlements which has witnessed such effects. The ancient city of Teos is situated on the shores of Western Anatolia on the edge of Siğacık Bay. This antique city in the town of Sığacık in Seferihisar, İzmir province, spreads over a wide area along the east-south eastern slope and the slopes of the Ekmeksiz hill ridge extends N-S which lies parallel to the coast. The city was established and developed at the isthmus of a small peninsula (Isthmos). The results of archaeological research show that the city has a history of 3000 years. Old settlements such as the Ionian city of Teos, which had been established on the coast in the Middle Holocene, are now located inland from the shoreline and their natural environment has changed considerably. The results of paleogeography and geoarchaeology studies aiming to determine such changes have made important contributions to the Teos archeology project. In order to determine the paleogeographical characteristics of Teos, drilling operations were started by our team in the summer of 2018. In this area, 3 core drillings were conducted in a similar manner by a team from the University of Cologne in 2013, but the results were not published except for a brief report submitted to the excavation directorate.

In the first works carried out by our team, 4 core drillings were done. The first results of the drilling and field studies are as follows. The alluvial-colluvial filling layers of the plain of Çayırarası in the east of the ancient city of Teos, from the bottom to the top, respectively, are divided into four main units, namely marine environment sediments, coastal marsh environment, Çayırarası flood plain and Teos cultural layer. In the core drillings carried out in the Çayırarası depression, results could not be obtained because of the depth of the PreHolocene basement fills and bedrocks. C14 dating from Teos-2019-01 drilling shows the year to be 3320 BP (Calibrated). In the drilling of Teos-2018-02, a volcanic ash layer was found at a depth of 580-600 cm. As a result of element analysis, it was understood that the tephra sample determined in the drilling samples was compatible with the Minoan explosion of Santorini (Thera) island in the year 3650 BP. With this c14 date and these tephra samples, which have special meaning as guide layer for chronostratigraphical interpretations, the approximate date of the Holocene transgression surface and Bronze Age coasts around the Teos site was determined. Thus, the Middle Holocene (Nortgripian) coasts of the Siğacık-Teos surroundings (BP 7000-6000) are outlined. It can be stated that the depression to the east of the ancient city of Teos, which lies in the direction of K-G, had been a strait in the Early Bronze Age. Accordingly, based on the Holocene transgression of the Ekmeksiz hill ridge on which the ancient city of Teos was located, it was found that it had been an island in the years 7000-6000 BP (Middle Holocene). The port of the ancient city of Teos, known to have been founded in 1000 BC (BP 3000), and the section of the city extending from the urban area to the Çayırarası depressions are covered with alluvial-colluvial deposits carried by the floods of Yass1 creek and slope floods from the Bronze Age to the present., and these now fill the coastal plain. There is a small cove which was put into the Çayırarası depression during the first years of the city of Teos. This shallow sea, which intruded into the NE of the mole of the ancient harbor, provided the ideal port conditions that the ancient city could use. The first findings determined that more sediments were transported to the coastal section of the Çayırarası plain than to the Sığacık-Karagöl plain in the north and this section had become land beforehand. In the next period, it was understood that coastal marshes developed after which a settlement was founded on the flood plain. In addition to this, the tectonic characteristics of Teos affected by many destructive earthquakes will be investigated in detail in field studies to be carried out this year. 


\section{GİISŞ}

Batı Anadolu kıyılarında Holosen boyunca meydana gelen doğal çevre ve kıyı çizgisi değişmeleri tarih öncesinden beri buralarda bulunmuş kültürler ve yerleşimleri etkilemiştir. Son buzul maksimumuyla birlikte deniz seviyesinde meydana gelen değişimler kıyı çizgisinin ve çevresindeki kıyı düzlüklerinin doğal çevre koşullarının değişmesine neden olmuştur. Ege kıyılarımızda yer alan Teos bu gibi etkilerin görüldüğü antik kıyı yerleşimlerinden biridir (Şekil 1).

Doğal çevre ve insan arasındaki ilişkileri inceleyen coğrafya disiplini geçmiş dönemlerdeki etkileşimi paleocoğrafya ve jeoarkeoloji başlıkları altında ele almaktadır (Butzer, 1982; Kayan, 1998; Weiner, 2010). Paleocoğrafya özelliklerinde meydana gelen değişmelerin insanlar üzerindeki etkilerini ve belirli bir dönemin insanlarının çevre ile etkileşimini arkeolojik buluntu-kazı alanlarında ve yakın çevrelerinde açıklayan disiplin jeoarkeolojidir ve paleocoğrafyanın bir parçasıdır. Teos gibi antik kıyı kentlerinin çevresinde meydana gelen ortam değişmelerinin izlerini yeni teknik imkanlardan da yararlanılan paleocoğrafya ve jeoarkeoloji çalışmaları ile araştırmak mümkündür. Teos çevresindeki Çayırarası (Kocaçay) kıyı ovasının alüvyon katmanlarında meydana gelmiş doğal çevre değişmelerinin bulguları bulunmaktadır. $\mathrm{Bu}$ izlere ulaşmak ve incelemek için alüvyal dolguların katmanlarını kesen delgi sondajların yapılması gerekmektedir.

Holosen'de kıyı çizgisi ve buna bağlı olarak jeomorfolojik unsurlar deniz seviyesinin hızla yükselmesine bağlı olarak hızla değişmiştir. Deniz seviyesi $-130 \quad$ m'den (son glasyal maksimumuyla beraber) Orta Holosen'e kadar bugünkü seviyesine ulaşmıştır. Bunun sonucunda özellikle akarsu ağızlarından ve alçak kıyı düzlüklerinden iç kesimlere sokulup koy ve körfezler oluşturmuştur (Kayan, 1988, 1996, 1998, 2000; Kayan ve Öner, 2003, 2006; Öner, 1997a, 1997b, 1999, 2003; Öner ve Vardar, 2018; Vardar ve Öner, 2016, 2017; Öner, Doğan, İlhan, Yaman ve Kayan, 2018; Vardar, 2018). Orta Holosen'de deniz seviyesi yükselmesi durmuş, bunun sonucu koy ve körfezler alüvyonlarla dolmuştur. Buna bağlı olarak kıyı çizgisi denize doğru ilerlemiștir. Bu dönemde kıyılarda liman kentleri zamanla kıyı çizgisinden içerilerde kalmış, önemlerini yitirmiş ve terk edilmişlerdir. Paleocoğrafya ve jeoarkeoloji araştırmalarımız antik kıyı yerleşmelerindeki arkeolojik kazı çalışmalarına katkılar yapmıştır. Bu yerleşim alanlarının iyi örneklerinden biri de bu çalışmanın konusu olan Teos'tur (Şekil 1).

Teos antik kenti Batı Anadolu kıyılarında Sığacık körfezi kenarında yer almaktadır (Şekil 1). İzmir ili Seferihisar ilçesi Sığacık beldesinde bulunan antik kent kıyıya paralel uzanan K-G doğrultulu bir sırtın doğu-güney doğu yamacı ile etekleri boyunca geniş bir alana kurulmuştur (Şekil 2). Kent, küçük bir yarımadanın kıyı kesiminde kurulmuş ve gelişmiştir (Kadıoğlu, Adak, Özbil, Yalçın ve Polat, 2012). Antik kentin doğusunda K-G doğrultulu Çayırarası kıyı ovası bulunmaktadır (Şekil 2, 3). Ova batıdan Ekmeksiz tepe sırtları, doğudan Bedelkaya, Mangır, Alaca, Çarık, Hamitefendi, Göz ve Taşlık tepeleri ile sınırlanır (Şekil 4). Bu tepeler daha doğuda bulunan Seferihisar ovasını Çayırarası ovasından ayırmaktadır. Çayırarası ovası denizden 912 m yüksekliğinde olan Kartal tepeden doğan Yassıçay'ın taşıdığ1 alüvyonların K-G doğrultulu Sığacık depresyon tabanında birikmesi ile oluşmuştur. Kıyı ovası deniz seviyesinden 1-3 m yükseklikte oldukça alçak bir yüzeye sahiptir. Çayırarası ovası kuzey kenarında silik bir su bölümü ile Sığacık limanı

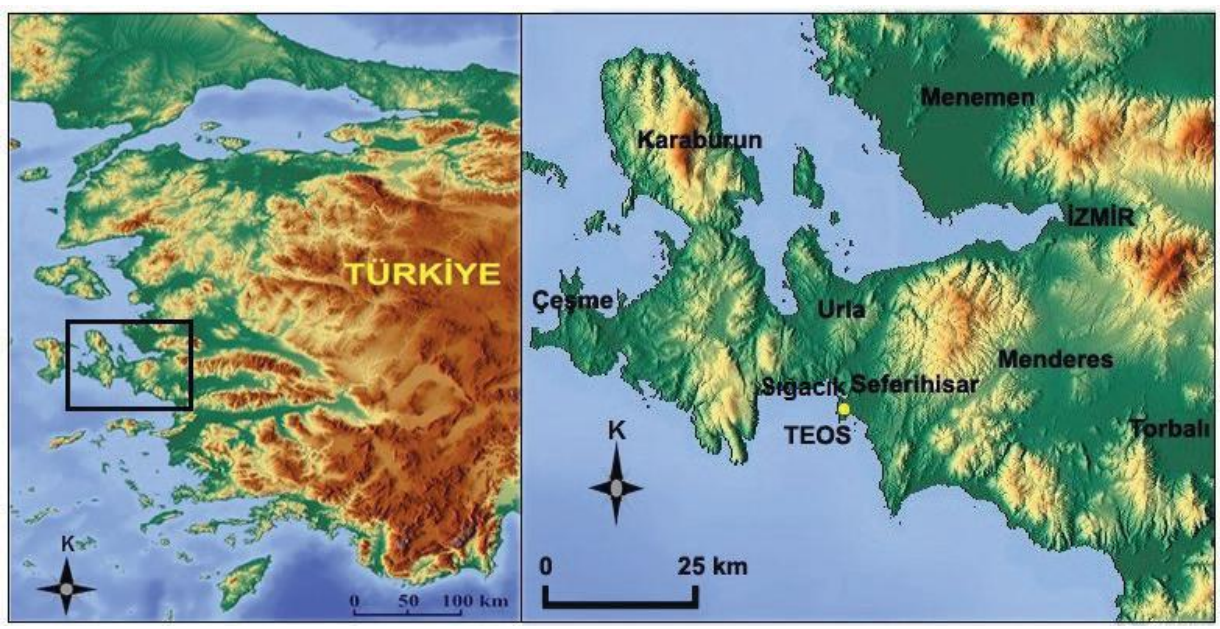

Şekil 1: Teos antik kentinin konumu.

Figure 1: Location of Teos ancient city. 


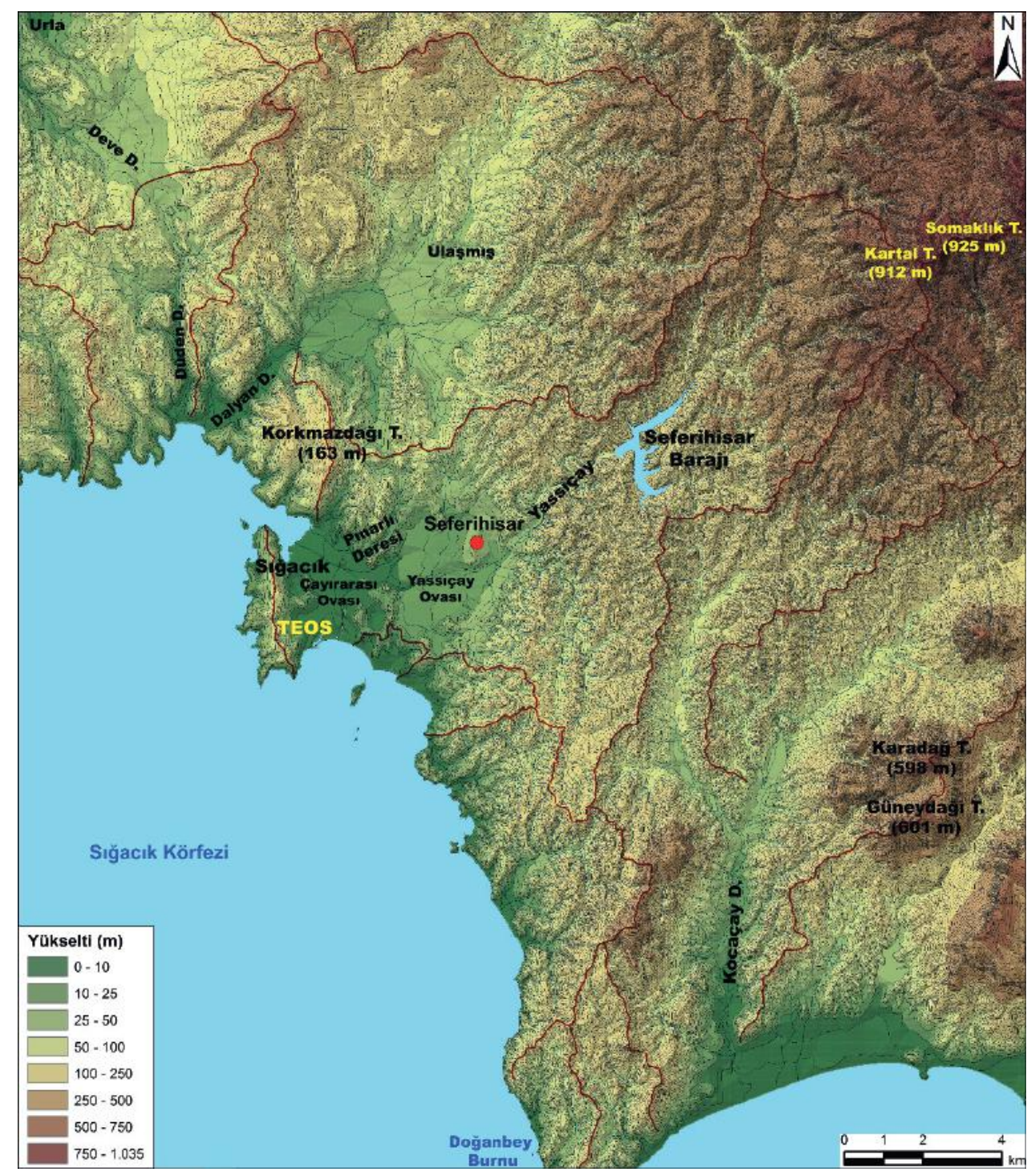

Şekil 2: Teos-Sığacık-Seferihisar ve çevresinin topografya haritası.

Figure 2: Topographic map of Teos-Sığacık-Seferihisar and surrounding.

yakınlarında denize dökülen Pınarlı ve Liman derelerinin havzalarından ve düzlüğünden ayrılmaktadır (Şekil 2, 4). Teos antik kenti kalıntıları ve kentten taşınan malzemenin birikmesine bağlı kültürel dolgu Ekmeksiz tepe sırtlarının doğu eteği boyunca Yassıçay’ın taşıdığı alüvyonlara karışmış ya da alüvyonlarca örtülmüştür. Ekmeksiz tepe sırtlarından taşınan kolüvyal materyal etek bölümünde bol arkeolojik materyal içeren daha kaba tane boylu bir dolgu meydana getirmiştir (Şekil 5).

\section{Arkeolojik Özellikler}

Teos'un Ion kolonizasyonu döneminde kurulduğunu (Strabon, 2000) ve Protogeometrik Dönem'den beri var olduğu bildirmektedir (Kadığlu ve Özbil, 2015). İon bölgesinin görkemli bir kenti olduğu kabul edilen Teos'un Mısır'a kadar uzanan ticari ilişkiler belirlenmiştir. Pers istilası sonucu büyük ölçüde terk edilen kent daha sona birçok göçmenin geri gelmesi ile refah seviyesi oldukça yükselmiştir (Kadığlu ve Özbil, 2015).

Ionia kıyılarında önemli zarara yol açan MÖ 304 yılındaki depremden Teos da kötü etkilenmiştir (Kadığlu ve Özbil, 2015). Teos'a MÖ 241-197 tarihlerinde Pergamon Krallığı ve MÖ 138133 yıllarında Roma imparatorluğu egemen olmuştur (Kadığlu ve Özbil, 2015). Kentin önemi Roma döneminde de devam etmiştir (Kadığlu ve Özbil, 2015). Augustus sikkelerine bağlı olarak kentte Augustus kültü bulunduğu ifade edilmektedir (Kadığlu ve Özbil, 2015). Sonraları kentin önemini kaybettiği ve Orta Çağ’a kadar küçük de olsa var olduğu anlaşılmıştır (Kadıoğlu ve Özbil, 2015). Kentteki diğer bir kült olan Dionysos'un etkisi ile MÖ 3. yüzyılda, birçok filozof, şair, 


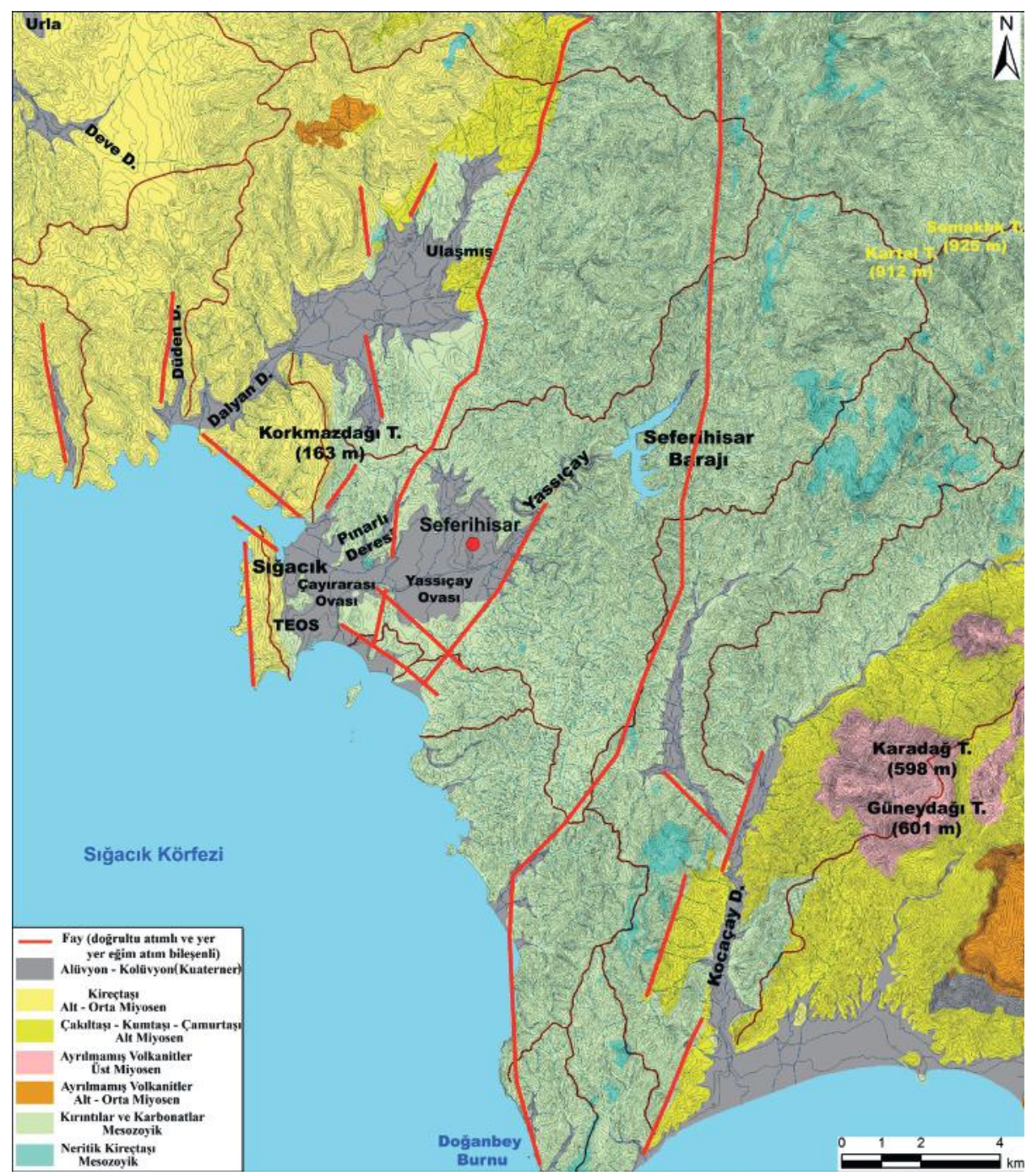

Şekil 3: Teos-Sığacık-Seferihisar ve çevresinin jeoloji haritası (MTA 1/500.000 ölçekli jeoloji haritasından yararlanılarak hazırlanmıştır).

Figure 3: Geological map of Teos-Sığacık-Seferihisar and surrounding (Prepared using MTA 1 / 500.000 scale geology map).

müzisyen, tiyatrocu ve şarkıcının burada yaşadığı bilinmektedir (Kadığlu ve Özbil, 2015).

Kent yakın çevresindeki mermer ocakları Antik dönemde kent yakınındaki mermer ocakları etkin işletilmiştir. Afrikano (Er, 2011), Bigio ve koyu renkli mermerleri bu ocaklardan çıkarılarak işlenmiştir (Kadıŏlu, 2016; Adak ve Kadıŏglu, 2017). Bu mermer ocaklarından en önemlisi olarak Karagöl antik işliğidir (Kun ve Türkmen, 2001; Kadıŏglu, 2016; Adak ve Kadığlu, 2017).

Teos antik kentindeki 1764-1765 tarihlerinde İngiliz Dilettanti Cemiyeti (Society of Dilettanti) adına R. Chandler ve N. Revett tarafından yapılan araştırmalar Teos kentindeki ilk çalışmalar olarak bilinmektedir. 1924 ve 1925 'te iki y1l süren Fransız kazıları ise Y. Bequignon ve A. Laumonier tarafindan gerçekleştirilmiştir. Fransız kazılarından sonra 1962-1967 yılları arasında Ankara Üniversitesi’nden Doç. Dr. Y. Boysal ve Dr. B. Öğ̈̈n Teos antik kentinde kazı ve araştırmaları sürdürmüştür. Bu dönemdeki çalışmalar Teos antik kentinde yerleşimin Protogeometrik Dönem'den itibaren (MÖ 1000 civarı) var olduğunu göstermektedir ("Teos kent tarihi”, 2020). Mimar D.M. Uz Dionysos Tapınağı ve Arkaik Tapınak’taki yapıların planlarını çıkarmak adına 1980 ile 1992 yılları arasında sondajlar yapmıştır. 1993-1996 yıllarında kısa süreli yüzey araştırmaları kapsamında Orta Doğu Teknik Üniversitesi'nden N. Tuna, yapıların plan ve rölöveleri üzerine çalışmıştır. 2010 yılında Ankara Üniversitesi'nden Prof. Dr. Musa Kadıŏglu başkanlığında yeniden başlayan kazı ve restorasyon çalışmaları halen devam etmektedir (“Teos araştırma tarihi”, 2020). Paleocoğrafya araştırmaları ekibimiz çalı̧̧malara 2017 yılında katılmış ve alanda iki yıl boyunca delgi sondajlar yapmıştır. 


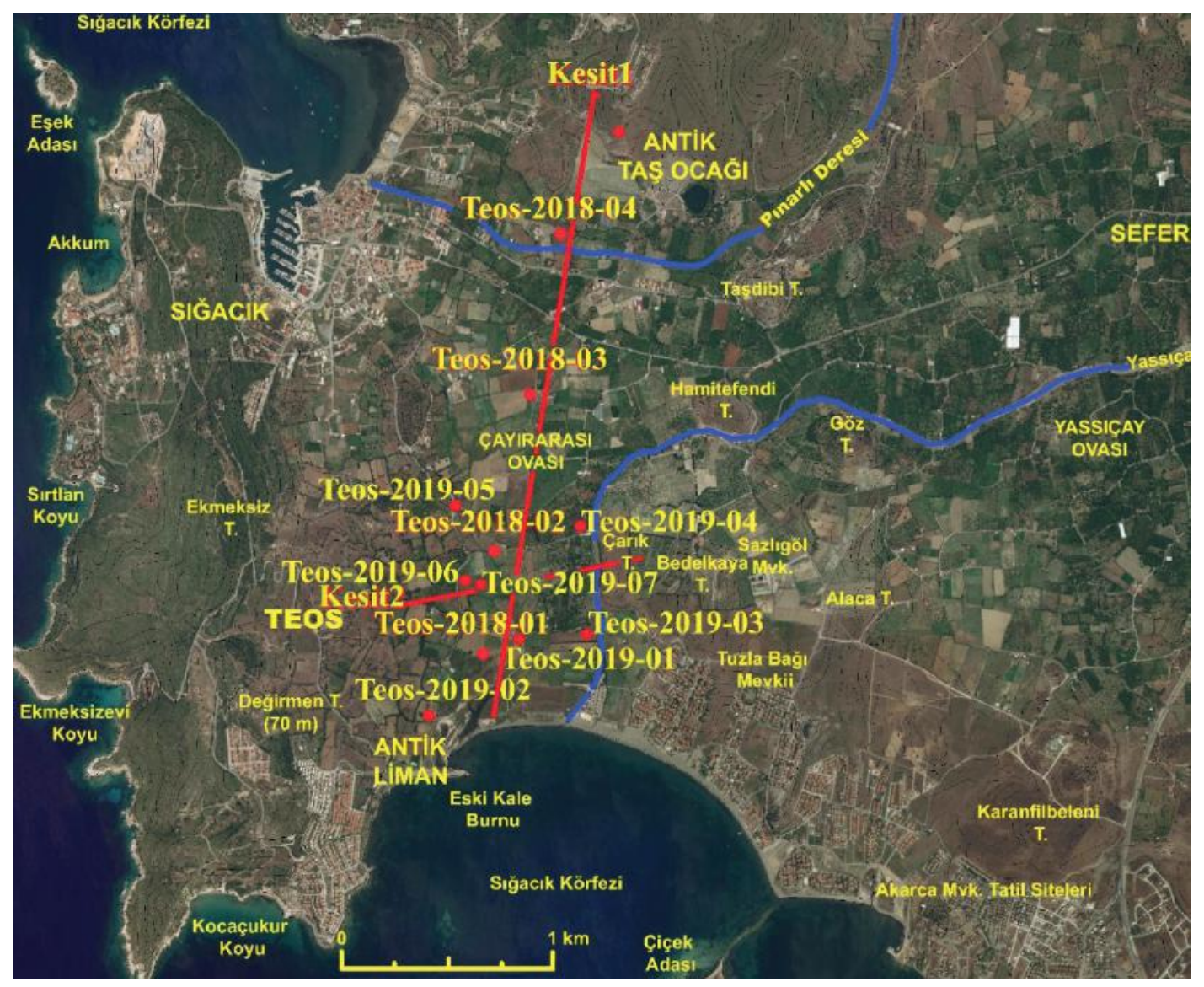

Şekil 4: Sondaj noktalarının konumu ve kesit hatları.

Figure 4: Locations of the core drilling points and the cross-section lines.

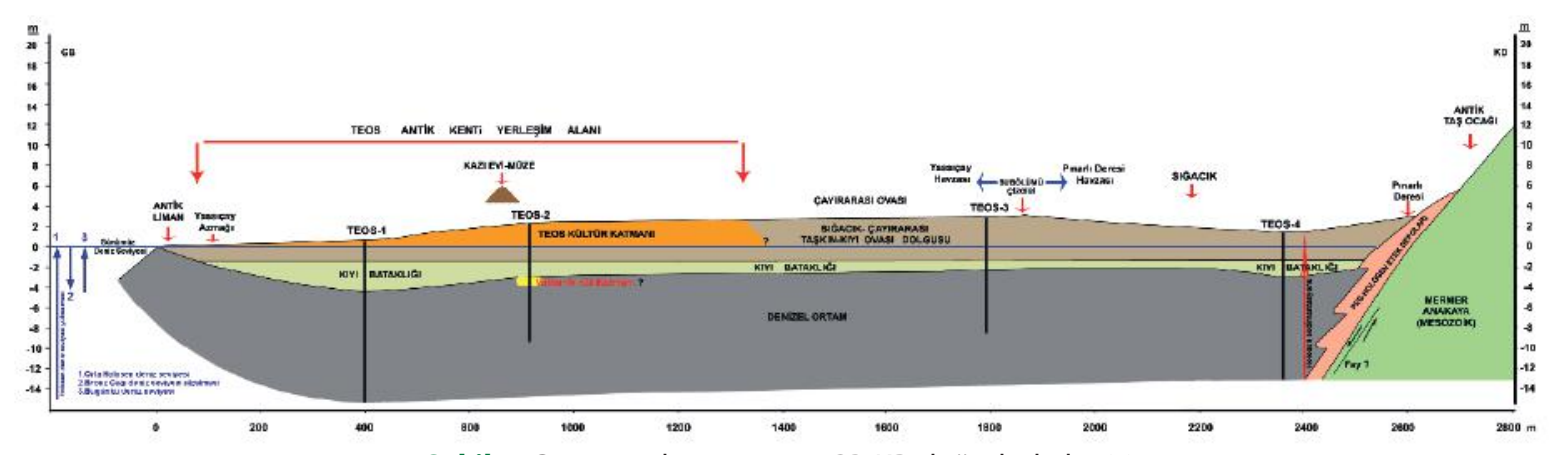

Şekil 5: Çayırarası kıyı ovasının GB-KD doğrultulu kesiti.

Figure 5: The SW-NE cross-section of the Çayırarası coastal plain.

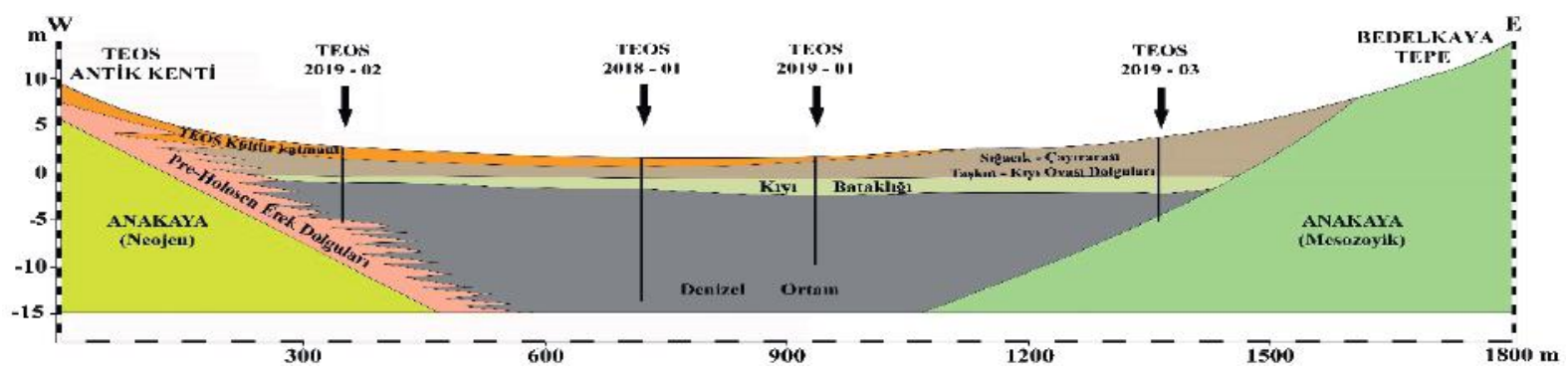

Şekil 6: Çayırarası kıyı ovası güney kesiminin batı-doğu doğrultulu kesiti.

Figure 6: The west-east cross-section of the southern part of Çayırarası coastal plain. 


\section{Jeolojik-Jeomorfolojik Çerçeve}

Seferihisar ve yakın çevresinin jeolojik özellikleri üzerine birçok çalışma yapılmıştır (Erdoğan, 1990; Ocakoğlu, Demirbağ \& Kuşcu, 2004; Denizlioğlu vd., 2005; Emre, Özalp, Doğan, Özaksoy, Yıldırım ve Göktaş, vd., 2005; Ocakoğlu ve Demirbağ, 2005; Bakak, 2016). Özellikle jeolojik özellikler oldukça detaylı olarak ele alınmıştır (MTA 1/500.000 ölçekli jeoloji haritası 2017) (Şekil 3).

Anadolu'nun batısı Paleotektonik birimlerinin yapısal özelliklerine göre kuzeydoğu-güneybatı yönlü üç kuşağa ayrılmaktadır. Bunlar doğudan batıya doğru kristalin metamorfik kayaçlardan meydan gelen Menderes masifi, ikincisi İzmirAnkara zonu ve en batıda Karaburun kuşağıdır (Erdoğan, 1990) (Şekil 3). Orta-Üst Miyosen'den günümüze devam eden ve Batı Anadolu'daki grabenleri oluşturan doğu-batı doğrultulu Neotektonik yapılar daha eski tektonik zonları kesmiştir (Dewey ve Şengör, 1979; Şengör, 1980).

Batı Anadolu ve Ege bölgesi neotektonik dönem ile birlikte yoğun kuzey-güney yönlü gerilmeye uğramıştır. Günümüzde de devam eden açılma ve gerilme hareketlerine bağlı olarak Batı Anadolu'da birbirine paralel pek çok graben, küçük çaplı havzalar meydana gelmiştir. İzmir ve çevresinde bulunan normal faylar Karaburun-Foça açıklarında, İzmir körfezinin iç kısımlarında Alaçatlı, Teke ve Kuşadası açıklarında gözlenmektedir. Normal faylar doğrultu atımlı faylar tarafindan kesilmektedir (Şekil 3). Bunlardan biri de Teos-Sığacık çevresinin şekillenmesini kontrol eden doğrultu atımlı Seferihisar fayıdır (Ocakoğlu vd., 2004; Emre vd., 2005; Bakak, 2016). Bu fay sağ yönlü doğrultu atımlı özelliğe sahip faydır (Denizlioğlu vd., 2005).

Seferihisar çevresinin eski litolojik birimleri kristalin şistlerdir. Paleozoik yaşlı birimlerde altta gnays, mikaşist, kloritşist ve şisti kuvarsitler üstte mermerler bulunur (Akartuna, 1962) (Şekil 3). Kretase birimleri eski kristalin temel üzerine diskordan olarak gelmektedir (Akartuna, 1962). Bunların üzerine gelen Miyosen formasyonları alt ve üst seri olarak iki bölümde ele alınmaktadır (Akartuna, 1962). Alt seri; konglomera, gre, marn, kiltaşı, volkanik tüfler ve kalkerlerden, üst seri; kalkerler, marn, kiltaşı ve volkanik tüflerden meydana gelmektedir (Akartuna, 1962). Yüksek alanların etek bölümlerinde görülen ve Miyosen üzerine diskordan gelen Pliosen depoları kırmızı renkli, killi, marnlı, kumlu ve çakıllıdır. Kristalin şistler Hersinien orojenezinde, Kretase ve Neojen formasyonları Alpin orojenezinde kıvrılıp kırılmıştır (Akartuna, 1962). Alanda görülen volkanik kayaçlar Miyosen dönemindeki volkanizmaya aittir (Akartuna, 1962). Teos çevresindeki yapılar açısından mermer önemli bir yapı malzemesidir. Teos kuzeyindeki Karagöl antik mermer ocağı gibi mermer yapılı tepeler Seferihisar çevresindeki Mesozoik yaşlı birimlere dahildir (Kun ve Türkmen, 2001) (Şekil 3). Özellikle Africano tipi mermer Teos için özel bir yap1 unsurudur.

\section{İklim, Bitki Örtüsü ve Toprak Özellikleri}

İklim özellikleri kıyı düzlüklerinin gelişimi sırasındaki flüvyal-kolüvyal dinamiklerin anlaşılması için önemlidir. Teos güneyindeki Çayırarası ovasının gelişimi için özellikle iklimin sıcaklık ve yağış elemanlarının özelliklerinin ortaya koyulması gereklidir. Sığacık çevresinin sıcaklık ve yağış özelliklerinin ortaya konulması için Seferihisar rasat istasyonu verilerinden yararlanılmıştır. Seferihisar'ın ortalama sıcaklık değeri 16,9 ${ }^{\circ} \mathrm{C}$ 'dir. Sicaklık değerleri Ocak ayında $4,6{ }^{\circ} \mathrm{C}$ 'ye kadar düşerken, Temmuz ayında $32,9{ }^{\circ} \mathrm{C}$ 'ye kadar çıkabilmektedir. Sıcaklık değerleri $0{ }^{\circ} \mathrm{C}$ 'nin altına düşmemekte ve yaz aylarında iç kesimlerdeki gibi $40{ }^{\circ} \mathrm{C}$ 'lerin üzerine çıkmamaktadır. Yıllık sıcaklık amplitüdü $19,7{ }^{\circ} \mathrm{C}(2016)$ ile $15,7{ }^{\circ} \mathrm{C}$ (1976) arasında değişmektedir ve değerler düşüktür (Yaman, 2018). Bu özellikler denize olan yakınlık, mutlak nem oranının yüksek ve yükseltinin deniz seviyesine yakın olması ile ilişkilidir (Erlat, 2003). Seferihisar'da yıllık ortalama yağış 623,6 mm'dir. Yağışın yıl içerisinde dağılışı düzensiz bir dağılım göstermektedir. Yağış miktarının yıl içerisindeki dağılımı batı rüzgârları ve gezici orta enlem depresyonlarının özellikleri ve etkinlik sürelerine bağlıdır (Koçman, 1993; Yaman, 2018). Seferihisar çevresinde Erinç indisine göre (Erinç, 1965) yarı nemli hatta bazı yıllar yarı kurak koşullar sahip Akdeniz iklimi hakimdir (Koçman, 1993).

Seferihisar bölgesinin Akdeniz ikliminin etkisi ile gelişen vejetasyon formasyonu elemanları; kızılçam, bozuk kızılçam, bozuk karışık baltalık, maki ve ağaçsız ot topluluklarıdır. Çalışma alanında bu vejetasyon formasyonlarının altında ve farklı litolojik birimler üzerinde gelişen topraklar farklılıklar göstermektedir. Kireçsiz Kahverengi Orman Toprakları, dik-çok dik ve sarp eğimli fliş anakayalar üzerinde yer alır (Günal, 1986; Altun, 2008). Seferihisar'dan Doğanbey'e kadar olan kesimde flişler ve kil yönünden zengin ana materyal üzerinde Rendzina toprakları gelişmiştir. Bunun yanında karbonatlar üzerinde oluşan Akdeniz toprakları geniş alana dağılmıştır (Altun, 2008). Teos-Sığacık-Seferihisar çevresinde Çayırarası-Seferihisar alüvyal kıyı düzlüğünü çevreleyen yüksek sahaların etek bölümlerinde kolüvyal topraklar yer almaktadır. 


\section{AMAÇ VE YÖNTEM}

Teos antik kenti çevresinde yerleşimin güney kenarındaki Çayırovası (Kocaçay) alüvyal kıyı ovasının Holosen boyunca gelişimi, jeoarkeoloji ve paleocoğrafya çalışmamızın ana konusudur. Kocaçay deresi Kuvaterner boyunca getirdiği alüvyonlarla K-G doğrultulu depresyonu denize doğru doldurmuştur. Holosen transgresyonu sonucu kıyı dolarak batıya doğru ilerlemiş ve bunun sonucunda kıyı çizgisi daha batıya taşınmıştır. Kıyıdaki doğal çevrenin değişmesi Teos'u etkilemiştir. Çayırarası ovasının şekillenmesi ve Kocaçay deltasının gelişimi limanı kullanılmaz duruma getirmiş ve kıyıdaki arazi kullanımı üzerinde etkili olmuştur.

Bu araştırmada, Teos çevresindeki doğal çevre değişmelerinin etkilerinin insan ile doğal çevre ilişkisi bağlamında yorumlanması, paleocoğrafya ve jeoarkeoloji değerlendirmelerinin yapılması amaçlanmıştır. Bunun için Çayırarası kıyı ovasının alüvyon katmanlarının ve yansıttıkları ortamların belirlenmesi gerekmektedir. Böyle bir araştırmanın gerçekleştirilebilmesi için Teos'un güneyindeki Çayırovası düzlüğü ve Kocaçay deresi deltasında alüvyon delgi sondaj yöntemi kullanılmıştır. Nitekim, Batı Anadolu'da yoğunlaşan delgi sondaj yöntemli jeoarkeoloji ve paleocoğrafya çalışmalarının önemli sonuçlar ortaya çıkarmıştır (Öner ve Kayan, 2006; Kayan ve Öner, 2013; Öner, 1997; Öner, 1999; Vardar, 2010, 2017, 2018a, 2018b).

2018-2019 yıllarında toplam 11 delgi sondaj yapılmıştır (Şekil 4) (Tablo 1). Derinlikleri 10-15 metreler arasında değişen bu sondajların sediman örneklerinin analizleri Ege ve İzmir Kâtip Çelebi üniversitelerinin laboratuvarlarında yapılmaktadır. Sondaj sediman örneklerinin tane boyutu, $\mathrm{pH}$, kireç, organik madde, element ve mikrofosil analizleri yapılmıştır ve yenileri yapılmaya devam etmektedir. Analizlerin verileri paleocoğrafya ve jeoarkeoloji değerlendirmelerinde fiziksel gözlemlerle birlikte ele alınmaktadır. Böylece detaylı yorumlar yapılabilmektedir.

Alınan örneklerin tarihlenmesi de bu çalışmalarda çok önem arz etmektedir. Bu amaçla, Teos-2019-01 sondajından yapılan C14 tarihlemesi GÖ 3320 (Calibrated) yılını vermiştir. Yeni tarihlemeler yaptırılmakta olup sonuçları beklenmektedir. Bunun yanında sondaj örneklerinde belirlenen tefra örneği kronostratigrafik bir k1lavuz seviyedir. Bu nedenle bu örneğin element analizleri yapılmıştır ve ilk sonuçlara göre GÖ 3650'de Santorini adasında meydana gelmiş ve Thera uygarlığına büyük zarar vermiş ünlü Minoan patlamasıyla uyumlu olduğu anlaşılmıştır. Bu sonuç Tunç çağına ait bir seviyenin yakalanması anlamına da gelmektedir. Belirtilen özelliği nedeniyle bu veri alüvyal katmanlarda ve kültür katmanlarıyla yapılacak korelasyonlarda kullanılmıştır.

\section{BULGULAR}

Teos çevresinde paleocoğrafya koşullarını araştırmaya yönelik ilk çalışma Helmut Brückner ve ekibince yapılmış ancak yapılan 3 sondajın sonuçları bir raporda sunulmuş ancak yayınlanmamıştır (Brückner, Stock \& Rauhut, 2013). Bu çalışmada Çayırarası kıyı düzlüğünde denizel sedimanlara ulaşıldığı belirtilmektedir. Bunun dışında Teos antik kenti çevresinde delgi sondaj yöntemi ile yapılan başka bir çalışma bulunmamaktadır. 2018-2019 yıllarından itibaren ekibimiz alanda çalışmaya başlamıştır. Bu metinde sondaj loglarının incelenmesi sonucu ilk değerlendirmeler ve analiz sonuçları ele alınmıştır. Sondaj log bilgileri sondaj sırası ile aşağıda verilmiş ve genel paleocoğrafya-jeoarkeoloji değerlendirilmesi yapılmıştır.

Tablo 1: Sondaj noktalarının konum, yükselti, derinlik ve tarih bilgileri.

Table 1: Location, elevation, depth and date information of core drillings.

\begin{tabular}{|c|c|c|c|c|c|c|c|}
\hline $\begin{array}{c}\text { Sondaj } \\
\text { Numarası } \\
\text { (Yıllar) }\end{array}$ & $\begin{array}{c}\text { Sondaj } \\
\text { Numarası } \\
\text { (Genel) }\end{array}$ & $\begin{array}{l}\text { Sondaj } \\
\text { Yükseltisi } \\
\text { (m) }\end{array}$ & $\begin{array}{l}\text { Sondaj } \\
\text { Derinliği } \\
\text { (m) }\end{array}$ & $\begin{array}{c}\text { Sondaj } \\
\text { Dip Yükseltisi } \\
\text { (m) }\end{array}$ & $\begin{array}{l}\text { Taban } \\
\text { Suyu } \\
\text { (cm) }\end{array}$ & $\mathbf{x}$ & $\mathbf{Y}$ \\
\hline TEOS - 2018 - 01 & TEOS - 01 & 0,50 & 15,00 & $-14,50$ & 145 & $481824.60 \mathrm{~d} D$ & $4227070.00 \mathrm{~m} \mathrm{~K}$ \\
\hline TEOS - 2018 - 02 & TEOS - 02 & 2,62 & 11,00 & $-8,38$ & 164 & $482191.60 \mathrm{~d} D$ & $4228959.01 \mathrm{~m} \mathrm{~K}$ \\
\hline TEOS - $2018-03$ & TEOS - 03 & 2,79 & 10,00 & $-7,21$ & 282 & $482056.20 \mathrm{dD}$ & $4228246.00 \mathrm{~m} \mathrm{~K}$ \\
\hline TEOS - 2018 - 04 & TEOS - 04 & 1,50 & 14,00 & $-12,50$ & 245 & $481883.20 \mathrm{~d} D$ & $4227534.00 \mathrm{~m} \mathrm{~K}$ \\
\hline TEOS - 2019 - 01 & TEOS -05 & 3,00 & 11,00 & $-8,00$ & 126 & $482019.10 \mathrm{~d} D$ & $4225437.32 \mathrm{~m} \mathrm{~K}$ \\
\hline TEOS - 2019 - 02 & TEOS - 06 & 3,00 & 7,80 & $-4,80$ & 137 & $481593.00 \mathrm{~d} D$ & $4225071.00 \mathrm{~m} \mathrm{~K}$ \\
\hline TEOS - $2019-03$ & TEOS - 07 & 5,00 & 7,70 & $-2,70$ & 161 & $482373.00 \mathrm{~d} D$ & $4225480.00 \mathrm{~m} \mathrm{~K}$ \\
\hline TEOS - 2019 - 04 & TEOS - 08 & 8,00 & 12,00 & $-4,00$ & 294 & $482290.00 \mathrm{~d} D$ & $4225914.00 \mathrm{~m} \mathrm{~K}$ \\
\hline TEOS - $2019-05$ & TEOS - 09 & 8,00 & 9,00 & $-1,00$ & $?$ & $481796.88 \mathrm{~d} D$ & $4225960.98 \mathrm{~m} \mathrm{~K}$ \\
\hline TEOS - 2019 - 06 & TEOS - 10 & 7,00 & 2,50 & 4,50 & 141 & $481758.56 \mathrm{~d} D$ & $4225689.21 \mathrm{~m} \mathrm{~K}$ \\
\hline TEOS - $2019-07$ & TEOS - 11 & 6,00 & 8,00 & $-2,00$ & 137 & $481823.92 \mathrm{dD}$ & $4225693.89 \mathrm{~m} \mathrm{~K}$ \\
\hline
\end{tabular}




\section{Teos-2018-01 sondajı:}

Teos-2018-01 sondajında, yüzeyde Teos antik kenti kültür katmanı ve onun altında steril bir katman olarak Çayırarası taşkın-kıyı ovası dolguları bulunmaktadır (Şekil 4, 5) (Tablo 1). Taşkın sedimanları eski bir kıyı bataklığını örtmektedir. Kıyı bataklığı sedimanlarının altında kalın bir denizel katman bulunduğu tespit edilmiştir. Denizel katmanın ne kadar derine kadar devam ettiği ve kalınlığı yapılan sondajlarla tespit edilmemiştir. Bunun yanında Transgresyon yüzeyi sedimanlarına, eski karasal dolgulara ve anakayaya ulaşılmamıştır.

\section{Teos-2018-02 sondajı:}

Teos-2018-02 sondajinda TEOS-1 sondajında ulaşılan katmanların özellikleri ile aynı alüvyal birimlere ulaşılmıştır (Şekil 4, 5, 7) (Tablo 1). Sondaj sırasında yüzeyden 580-600 cm derinde $10 \mathrm{~cm}$ kalınlığında Tefra katmanı bulunmuştur. $\mathrm{Bu}$ katmanın element analizleri henüz yapılmamıştır. Ancak Batı Anadolu ile ilgili tephra çalışmalarına ait veriler küllerin Santorini adasındaki Minoan patlamasıyla (MÖ 1630-1640) ya da Nsyros volkanının patlamalarıyla ile uyumlu olabileceğini düşündürmektedir. Santorini'nin Minoan patlaması ile ilgili literatürde birçok farklı tarihleme bulunmaktadır. Bunlar MÖ 1600 ile 1650 arasında değişmektedir (Sullivan, 1988; Manning, 1988; Yiğitbaşıoğlu, 2003; Ramsey, Manning \& Galimberti, 2004; Friedrich, 2000; 2013; Friedrich vd., 2006; Friedrich \& Heinemeier, 2009). Vespa ve diğerleri (2006) son 150.000 yılda meydana gelmiş Santorini patlamalarını ele aldıkları çalışmada MÖ 1628 tarihini vermişlerdir. $\mathrm{Bu}$ çalışmamız sırasında yaptığımız element analizleri sonucunda Teos-2018-02 sondajında belirlenen tefra örneğinin GÖ 3650'deki Minoan

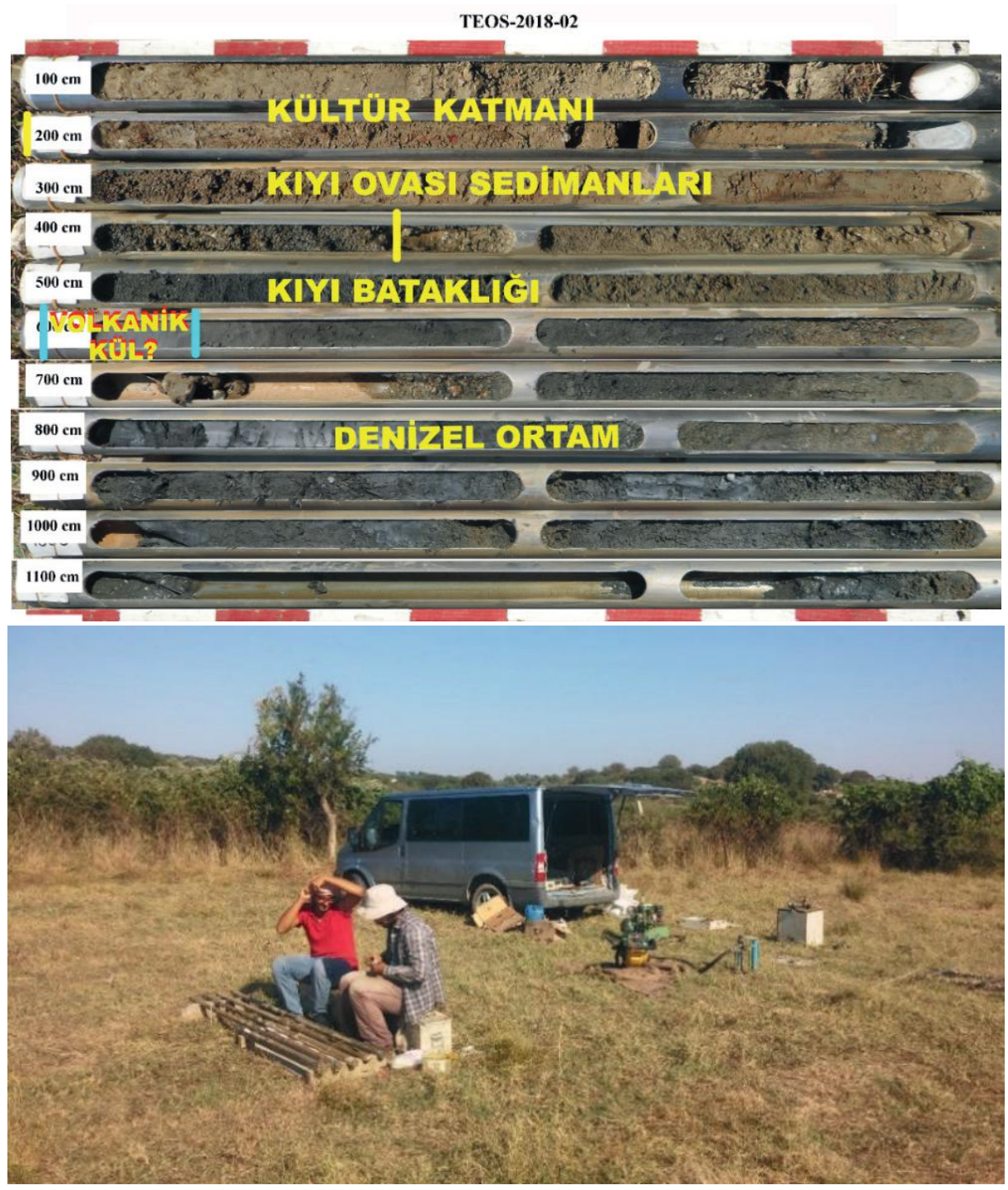

Şekil 7: Sondaj loglarından (üstte) ve sondaj çalışmalarından bir görünüm Figure 7: Images from core drilling log and studies. 
patlamasıyla uyumlu olduğu anlaşılmıştır. Ayrıca Teos-2019-01 sondajından alınan örneğin C14 tarihlenme sonucu olan GÖ 3320 tarihi bu veriyi doğrulamıştır

Batı Anadolu'da yapılmış önceki çalışmalarda, Gölcük'te (Bozdağ) (Sullivan, 1988, 1990; Vardar ve Altıner, 2003), Gölhisar gölünde (Burdur) (Eastwood, Pearce, Westgate \& Perkins, 1998; Eastwood vd., 1999; Eastwood, Tibby, Roberts, Birks, Lamb, 2002), Köyceğiz'de (Muğla) (Sullivan, 1988, 1990), Eşen ovasında Letoon-Patara çevresinde (Öner, 1997a, 1997b, 1999, 2013), İzmir Bayraklı höyüğünde (Öner ve Kayan, 2006; Kayan ve Öner 2013; Öner, 2013) ve Marmara gölünde (Vardar 2018) Santorini tefrası (göl tortuları içinde) bulunmuştur (Tablo 1). Bunların yanında, Söğüt depresyonu ile Milet’te de bu küllerin varlığından bahsedilmiştir (Dunn, 2002). Son y1llarda arkeolojik kazı alanlarında da volkanik tefra örneklerine rastlanmıştır. Bağlararası (Çeşme) ve Tepecik (Çine) arkeolojik kazılarında tefra bulunmuştur (Düvenci, 2013; Omaç, 2014; Şahoğlu, Böyükulusoy, Erbil, Erkanal ve Tuğcu, 2014) (Tablo 1). Küllerin göl-bataklık-sığ deniz-lagün gibi ortamlarda birikmesi doğaldır. Ancak höyüklerde de bulunmuş olması dikkate değer bir durumdur (Vardar ve Öner, 2016, 2017; Öner ve Vardar, 2018). Teos çevresi de bu yaklaşımla Tefra örnekleri açısından dikkatle araştırılmaktadır.

\section{Teos-2018-03 sondajı:}

Teos-2018-03 sondajında TEOS antik kentinden taşınan kültürel sedimanlaraya da in-situ kültür katmanına rastlanmamıştır (Şekil 4, 5) (Tablo 1). Bu sondajda yaklaşık $4 \mathrm{~m}$ kalınlığında Çayırarası taşkın-kıyı ovası sedimanlarına ulaşılmıştır. Bunun altında ince bir kıyı bataklığı dolgusu ve önceki iki sondajdan daha kalın denizel sediman katmanına ulaşılmıştır. Yassıçay ile Pınarlı deresi arasındaki silik su bölümüne yakın olan bu sondaj her iki akarsuyun havzası arasındaki bu kesimin güneyine göre daha sonra kara haline geldiğini ortaya koymuştur.

\section{Teos-2018-04 sondajı:}

Teos-2018-04 sondajinda tamamiyla steril tabakalar kesilmiştir. Kültürel bulgulara rastlanmamıştır (Şekil 4, 5) (Tablo 1). Teos-2018-03 sondajındaki katman özellikleri aynı devam ederken, kıyı bataklığı sedimanlarının Teos-2018-03 sondajına göre hafifçe daha kalın bir katman halinde olduğu belirlenmiştir.

\section{Teos-2019-01 sondajı:}

Teos-2019-01 sondaj1, Teos-2018-01 sondajının yaklaşık 200 metre kuzeydoğusunda yapılmıştır (Şekil 4) (Tablo 1). Yüzey yükseltisinin 3 metre olduğu noktadan 11 metre derine inilmiş, günümüz deniz seviyesinin 8 metre altına inilmiştir. Taşkın ovası sedimanları, kıyı bataklığı ve denizel sedimanlar bu sondajda ayrılan ana sediman birimleridir (Şekil 4). Yüzeyden 11 metre derine inilmesine rağmen Holosen öncesi dolgulara ulaşılamamıştır. Yüzey ile $210 \mathrm{~cm}$ arasında taşkın ovası sedimanları, $210 \mathrm{~cm}$ ile $475 \mathrm{~cm}$ arasında kıyı bataklığ 1 geçişmiştir. Taşkın ovası sedimanları içerisinde az miktarda seramik kırıntıları gözlenmiş̧ir. $475 \mathrm{~cm}$ ile $1100 \mathrm{~cm}$ arasında denizel sedimanlara ulaşılmıştır. Sondaj denizel sedimanlar içerisinde sonlandırılmıştır (Şekil 4, 6). Bu sondajın $1000 \mathrm{~cm}$ derinliğinden yapılan C14 tarihlemesi GÖ 3320 (Calibrated) yılını vermiştir. $\mathrm{Bu}$ durumda bu sondajın bulunduğu alan milat yıllarında karalaşmaya başlamıştır. Ancak daha güneyde hala bir koyun varlığını sürdürdüğü denizel sedimanlardan anlaşılmaktadır.

\section{Teos-2019-02 sondajl:}

Liman kalıntılarının yaklaşık 250 metre kuzeyinde, Teos2018-01 sondajının yaklaşık 350 metre güneybatısında yapılan Teos-2019-02 sondajında yüzeyden $780 \mathrm{~cm}$ derinliğe kadar inilmiştir (Şekil 4) (Tablo 1). Sondajda 0-165 cm arasında yapı ve seramik kalıntılarının bol miktarda gözlendiği kültür katmanı ve taşkın - kıyı ovası sedimanları geçilmiştir. 165-235 cm arasında kıyı bataklı̆̆ ve $235-735 \mathrm{~cm}$ arasında denizel sedimanlara ulaşılmıştır. Sondajın 735 cm'sinden sonra 2018'de sondajlarında ulaşılamayan Holosen öncesi dolgulara ulaşılmış ve sondaj bu seviyede sonlandırılmıştır (Şekil 4, 6).

\section{Teos-2019-03 sondajl:}

Teos-2019-01 sondaj1 yaklaşık 350 metre doğusunda Kocaçay dere yatağının 7-8 metre batısında yapılan Teos-201903 nolu sondajda yüzeyden $770 \mathrm{~cm}$ derine inilmiştir (Şekil 4) (Tablo 1). 0-440 $\mathrm{cm}$ arasında taşkın ovası sedimanları geçilmiştir. Taşkın ovası sedimanları içerisinde yapı ya da seramik kalıntılarına rastlanmamıştır. 440-645 cm arasında kıyı bataklığı ve $645-750 \mathrm{~cm}$ arasında denizel sedimanlara ulaşılmıştır. Sondajın 750-770 cm'lerde anakayaya ulaşılmıştır (Şekil 4, 6).

\section{Teos-2019-04 sondajı:}

Teos-2019-03 sondajının yaklaşık 450 metre kuzeyinde Kocaçay dere yatağının 70 metre batısında mandalina bahçesinde yapılan Teos-2019-04 nolu sondajda yüzeyden $1200 \mathrm{~cm}$ derine inilmiştir (Şekil 4) (Tablo 1). Yüzey ile $845 \mathrm{~cm}$ arasında oldukça zor bir şekilde ilerlenilen ve kaba taneli sedimanların daha fazla oldu taşkın ovası sedimanları geçilmiştir. 845-935 kıyı bataklığı ve $935-1165 \mathrm{~cm}$ arasında denizel sedimanlara ulaşılmıştır. Sondajın 1165-1200 cm arasında ise anakayaya ulaşılmıştır. Teos-2019-03 nolu sondaj ile aynı hat üzerinde (Kuzey - Güney) üzerinde yapılan bu sondajda da yapı ve seramik kalıntılarına rastlanmamıştır (Şekil 4, 6). Bu sondajın en derin bölümünden 
alınan örnekler buranın yaklaşık GÖ 5000'lerde (c14) sı̆̆ bir denizel ortam olduğunu ortaya koymuştur.

\section{Teos-2019-05 sondajı:}

Teos-2019-05 sondaj1, Teos-2018-02 sondajının yaklaşık 170 metre kuzeybatısında, Teos-2019-04 nolu sondajın yaklaşık 500 metre batısında yapılmıştır (Şekil 4). Yüzey yükseltisinin 8 metre olduğu sondaj noktasından 9 metre derine inilmiştir (Tablo 1). Yüzey ile $365 \mathrm{~cm}$ arasında yapı ve seramik kalıntılarının gözlendiği kültür katmanı ve taşkın sedimanları geçilmiştir. Seramik kalıntıları 320-365 cm arasında taşkın sedimanları içerisinde bol miktardadır. $365-500 \mathrm{~cm}$ arasında kıyı bataklığı ve 500-845 cm arasında denizel sedimanlara ulaşılmıştır. Teos2019-02 nolu sondajda olduğu gibi Teos-2019-05 sondajında da 845 cm'den sonra Holosen öncesi dolgulara girilmiştir. Sondajda bu dolgular içerisinde sonlandırılmıştır (Şekil 4, 6).

\section{Teos -2019-06 sondajı:}

Teos-2018-01 nolu sondajın yaklaşık 330 metre kuzeyinde, Teos-2018-02 nolu sondajın 200 metre güneybatısında yapılmıştır (Şekil 4). Yüzey yükseltisinin 7 metre olduğu sondaj noktasından 2,5 metre derine inilmiştir (Tablo 1). $250 \mathrm{~cm}$ 'de rastlanılan yapı nedeniyle sondaj bu seviyede sonlandırılmıştır. $\mathrm{Bu}$ sondajda yüzey ile $250 \mathrm{~cm}$ arasındaki birim kültür katmanı olarak ayrılmıştır. Bu kültür katmanı içerisinde yapı kalıntılarına ait taş ve seramik kırıntıları görülmektedir (Şekil 4, 6).

\section{Teos-2019-07 sondajı:}

Teos-2019-07 sondajı, $250 \mathrm{~cm}$ 'de rastlanılan yapı kalıntıları nedeniyle sonlandırılan Teos-019-06 nolu sondajın yaklaşı 60 metre doğusunda yapılmıştır (Şekil 4). Yüzey yükseltisinin yaklaşı 6 metre olduğu noktadan 8 metre derine inilmiş ve günümüz deniz seviyesinin 2 metre altına ulaşılmıştır (Tablo 1). Sondaj da denizel sedimanlar içerisinde sonlandırılmıştır. Yüzey ile $265 \mathrm{~cm}$ arasında Teos antik kentinden taşınan kültürel sedimanlara ya da in-situ kültür katmanına rastlanmıştır. Teos-2019-06 nolu sondajda olduğu gibi bu seviyeler arasında bol miktarda yapıya ait kalıntılar ve seramik kırıntıları gözlenmiştir. $265 \mathrm{~cm}$ ile $555 \mathrm{~cm}$ arasında yaklaşık 3 metre kalınlığında Çayırarası taşkın-kıyı ovası sedimanlarına ulaşılmıştır. Bu seviyenin altında $555 \mathrm{~cm}$ ile $670 \mathrm{~cm}$ arasında kıyı bataklığı geçilmiştir. $\mathrm{Bu}$ birim içerisinde bitki kalıntıları da gözlenmektedir. $670 \mathrm{~cm}$ ile $800 \mathrm{~cm}$ arasında ise içerisinde makro boyutta gözlenen denizel sedimanlara ulaşılmış ve sondaj bu seviyede sonlandırılmıştır.

\section{Sondaj verilerine dayanan paleocoğrafya değerlendirmeleri}

Teos Çayırarası kıyı düzlüğü alüvyal dolguları farklı ortamları temsil eden 4 temel birime ayrılmıştır. Bunlar, en alttan (eskiden) en üste (yeniye) doğru sırasıyla; Denizel ortam sedimanları, kıyı bataklığı ortamı, Çayırarası taşkın ovası ve Teos kültür katmanıdır (Şekil 5, 6). Katmanların her birinin kotları günümüz deniz seviyesinden yaptığımız hassas ölçümlerden taşıdığımız kotlara göre belirlenmiştir. Sondaj alanındaki katmanların korelasyonu ve deneştirmesi için şunlar ifade edilebilir.

Çayırarası depresyonunun doğusundaki yamaçlar Mesozoik fliş-mermerler serisinden, batısındaki Ekmeksiz tepe ise Miyosen gölsel-karasal dolgularından meydana gelmektedir (Şekil 6). Bu depresyonun tabanı her iki kenarındaki kısa eğim atımlı faylarla denetlenmiş olup oldukça derindir.

Stratigrafik olarak en altta bulunan dolgular olan denizel sedimanlar Ekmeksiz tepe doğu eteğindeki Teos kenti bölümünde ve Çayırarası depresyonun en kuzeyindeki antik taş ocağ1 yamacında Pre-Holosen etek dolgularının üzerine gelmiştir (Şekil 5, 6). Bu dolguların dağılışını verebilmek için yeterince sondaj yapılmamıştır. Ayrıca oldukça ince bir katman olarak belirlenmiş ve yeterine veriye ulaşılamadığı için henüz ayrı bir birim olarak genel değerlendirmeye dahil edilmemiştir. $\mathrm{Bu}$ nedenle en alt dolgular olarak denizel sedimanlar kabul edilmiş ve denizel birimde henüz Holosen transgresyonu yüzeyine ait verilere ulaşılamamışıtır (Şekil 5, 6). Denizel sedimanların antik taş ocağ 1 ile Göz ve Bedelkaya tepelerine kadar sokulduğu belirlenmiş olup daha doğuya ulaştığına dair verilere henüz ulaşılmamıştır (Şekil 6, 8). Ancak, Orta Holosen'de denizin hemen hemen bütün depresyon tabanını kapladığı (Şekil 5, 6) ve buna göre Ekmeksiz tepenin Orta Holosen başlarında bir ada olduğu anlaşılmıştır (Şekil 8). Denizel sedimanlardaki bol sı̆̆ denizel foraminifer, molluks ve bivalvialar iç kesimlerde Seferihisar yönünde görülmemektedir. Bu durumda Çayırarası ovasından Seferihisar yerleşime uzanan ve Sığacık-Seferihisar arasında uzanan iç ovansında ayrıca çok sayıda sondajla araştırılması gereklidir.

Denizel ortam ile kıyı bataklığı geçiş zonunda tefra örnekleri belirlenmiştir. Teos-2018-02 sondajındaki volkanik kül örnekleri ilk analiz sonuçlarına göre Santorini volkanının günümüzden 3640 yıl önce gerçekleşmiş olan Minoan patlaması ile uyumludur (Şekil 7). Bu konu daha detaylı analizlerle araştırılmaya devam edilmektedir. Tefra tabakası 3640 yıl önceki kıyı ve kı1 bataklığının yakalanması için ilk bilgileri vermiştir. Sonraki sondajların yerleri buna göre saptanmış olacaktır. Böylece artan sondaj sayıs1 ile Holosen transgresyonundan günümüze günümüzden 3000, 2000, 1000 kıyıları rahatlıkla yeniden çizilebilecektir. 
Kıyı bataklığı dolguları Çayırarası depresyonunun kuzey ve güneyi boyunca denizel ortamın üzerine hemen hemen bütünüyle örtmektedir (Şekil 5, 6). Kıyı bataklığı; artan kıyı-bataklık bitkilerinin izleri, mikro fosiller ile ve daha çok karasal katkı ile ayrılmakta ve tüm depresyon tabanında çevresindeki yüksek alanların etek kesimlerine kadar sokulmaktadır (Şekil 5, 6).

Kıyı bataklı̆̆ı dolguları üzerine Çayırağası kıyı-taşkın ovası dolgular1-yüzey örtüsü gelmektedir. Bu alüvyal birim Ekmeksiz tepe doğusundaki depresyonun en güneyindeki antik limandan en kuzeydeki Sığacık kıyılarına (marinasına) kadar uzanmaktadır (Şekil 4, 5).

Teos kültür katmanlarının yerleşimin bulunduğu Ekmeksiz tepe doğu yamacı ve etekleri boyunca doğuya ve güneye doğru eğim yönünde taşındığı görülmektedir. Ekmeksiz tepenin doğu etekleri boyunca kolüvyal etken ve süreçlerle denetlenen yüzey aşınma-taşınma faaliyetleri sonucunda kültürel sedimanların Teos güneyindeki alüvyal kıyı düzlügünün (doğal) alüvyon katmanları içine ya da arasına ardalanmalı karıştığı görülmüş̧ür. Teos kültür katmanları güneydeki depresyonun orta bölümüne kadar uzanmaktadır (Şekil 5, 6). Yer yer iç içe (interfingering) çapraz katmanlar belirlenmiştir. Kültürel katmanlar ekmeksiz tepenin doğu etekleri boyunca Sığacık yerleşimi güneyine kadar uzanmaktadır (Şekil 5).

\section{SONUÇ}

Teos antik kenti çevresinde paleocoğrafya ve jeoarkeoloji çalışmalarının başlıca sonuçlar şunlardır. Teos antik kenti doğusundaki Çayırarası ovasının alüvyal-kolüvyal dolgu katmanları eldeki bilgilerin 1şı̆̆ında dört alüvyal birime ayrılmışıı (Şekil 5, 6). Çayırarası depresyonunda anakayaya sondajlarla ulaşılmamıştır. Bu depresyon tabanının ve anakayanın oldukça derin olduğunu ortaya koymuştur (Şekil 5, 6). Çayırarası depresyonunun tabanındaki anakayayı örten Holosen öncesine ait eski dolgulara derinde oldukları için ulaşılamamıştır. Bu dolgular çevredeki etek bölümlerinde takip edilebilmektedir (Şekil 5, 6). Bunun yanında en derini $15 \mathrm{~m}$ olan sondajlarımızla Holosen transgresyonu dolgularına da ulaşılmamıştır. En derini 15 m olan sondajlarımızda da Holosen transgresyonu dolgularına ulaşılmamıştır (Şekil 5, 6).

Çalışmalar sonucunda Sığacık-Teos çevresinin Orta Holosen (Nortgripiyen) kıyıları (GÖ 7000-6000) ana hatları ile belirlenmiştir (Şekil 8). Teos antik kentinin doğusunda K-G doğrultusunda uzanan Çayırarası ovasının bulunduğu depresyonun, son buzul maksimumuyla birlikte yükselen deniz seviyesine bağlı olarak denizin iç kesimlere sokulması sonucu günümüzdeki Sığacık kıyıları ile Antik liman arasında uzanan bir boğaz görünümünde olduğu saptanmıştır (GÖ 7000-6000

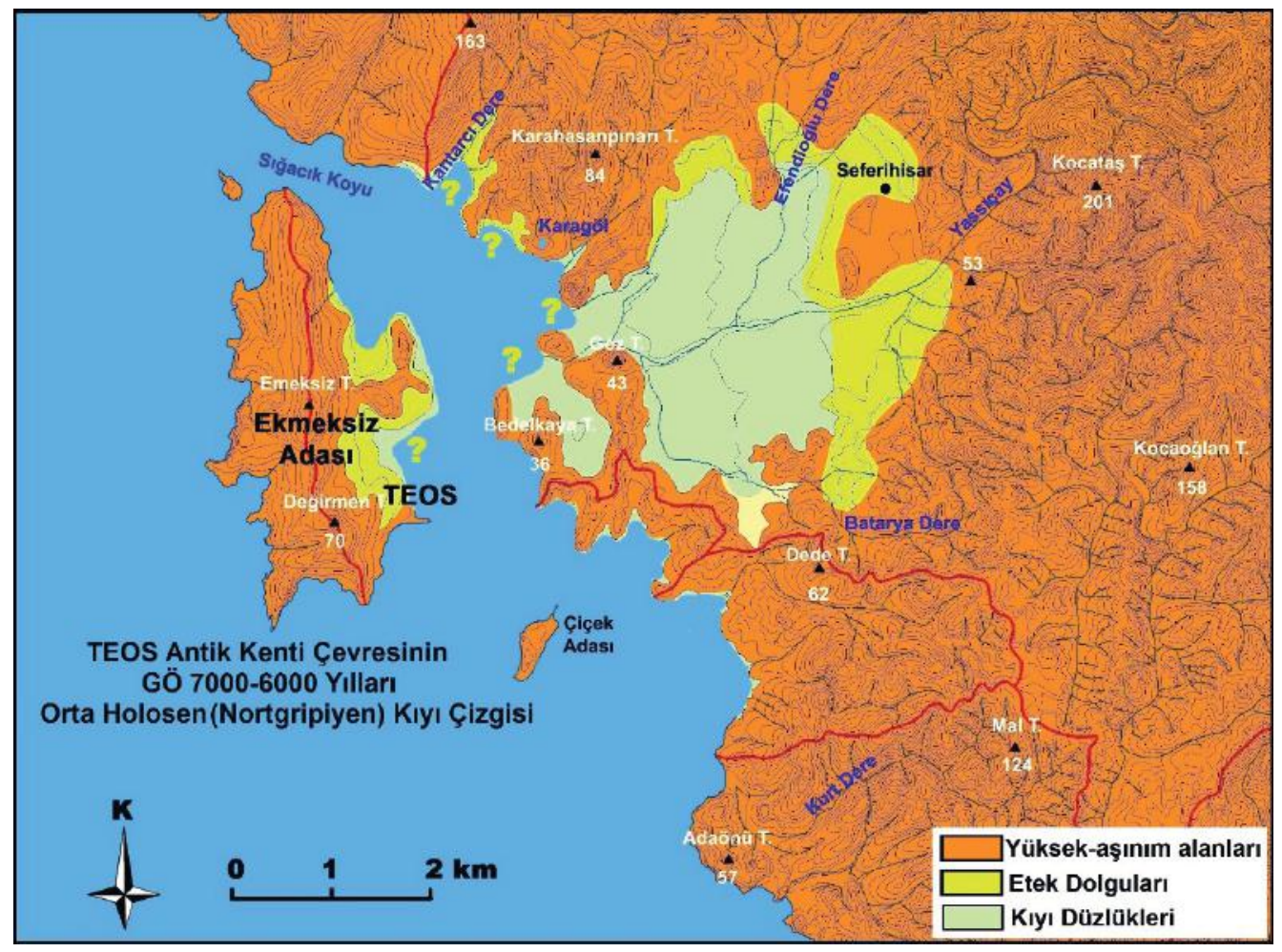

Şekil 8: Teos antik kenti çevresinin paleocoğrafya haritası

Figure 8: Paleogeography map of the Teos ancient city surroundings. 
yıllarında-Orta Holosen'de) (Şekil 8). Buna göre Erken Tunç Çağı evresinde Çayırarası ovasını bütünüyle bir boğaz görünümünde olduğu ifade edilebilir (Şekil 8). Brückner (2013) ve arkadaşları da bu kesimdeki sondajlarda denizel ortama ait bulgulara ulaşmışlardır. Ancak yeterli veri olmadığından paleocoğrafya haritası yapmamışlardır. Bu durumda, Teos antik kentinin üzerinde bulunduğu Ekmeksiz tepe sirtları Holosen transgresyonu sonucu GÖ 7000-6000 y1llarında (Orta Holosen'de) bir adadır (Şekil 8).

Eldeki ilk bulgular Çayırarası kıyı ovasının kıyı kesimine, kuzeydeki Sığacık-Karagöl antik taş ocağ 1 arasında yer alan Pınarlı deresi düzlüğüne göre daha fazla sediman ulaştığı ve bu bölümün kuzeyine göre daha önce kara haline geldiği belirlenmiştir. Bu kesimde önce sığlaşan kıyı bataklıklarının geliştiği ve bunun üzerine gelen taşkın ovasında ise yerleşimin başladığı anlaşılmıştır (Şekil 5, 6).

MÖ 1000 (GÖ 3000) yıllarında kurulduğu bilinen Teos antik kenti limanı ve kentsel alanının Çayırarası depresyonuna uzanan kesimi Yassıçayın taşkınları ve yamaç selleri ile alüvyal-kolüvyal birikintilerle örtülmüş Tunç Çağı'ndan günümüze kadar kıyı düzlüğü dolguları ile boğulmuştur (Şekil 5, 6, 8). MÖ 1000 (GÖ 3000) yıllarında Teos kentinin kurulması sırasında Çayırarası depresyonuna sokulan bir küçük koy bulunmaktadır. Liman mendireğinin KD'suna sokulan bu sığ deniz antik kent için ideal liman koşullarını sağlamışıı (Şekil 5, 6). Bu kıyının çizilebilmesi için gerekli iki enine kesit için sondajlar başlatılmıştır. Teos Antik kenti-Değirmen mevkii ve Bedelkaya tepesi arasında depresyonun enine Holosen paleocoğrafyası kesiti (Kesit 1) hazırlanmıştır. $\mathrm{Bu}$ sondajların ve yeni $\mathrm{C} 14$ tarihlemelerinin tamamlanmasının sonucunda son 6000 y1lın her bin y1lına ait kıyılar düzenli olarak çizilebilecektir.

Teos-2018-2 sondajında ulaşılan sığ ve sakin su koşullarını temsil eden sedimanların içinde, 580-600 cm'lerde altı-üstü tedrici geçişli bir bant şeklinde volkanik kül katmanı olduğunu düşündüğümüz sediman bulunmuştur (Şekil 5, 7). Bunun tespiti için gerekli element analizleri başlatılmıştır.

Çayırarası ovasının doğu-kuzeydoğu kesimlerinde Holosen transgresyonu kıyıları henüz belirlenememiş̧ir (Şekil 8). Önümüzdeki yıllarda yapılacak çalışmalar paleocoğrafyajeoarkeoloji konusundaki bu gibi soruların aydınlatılması için

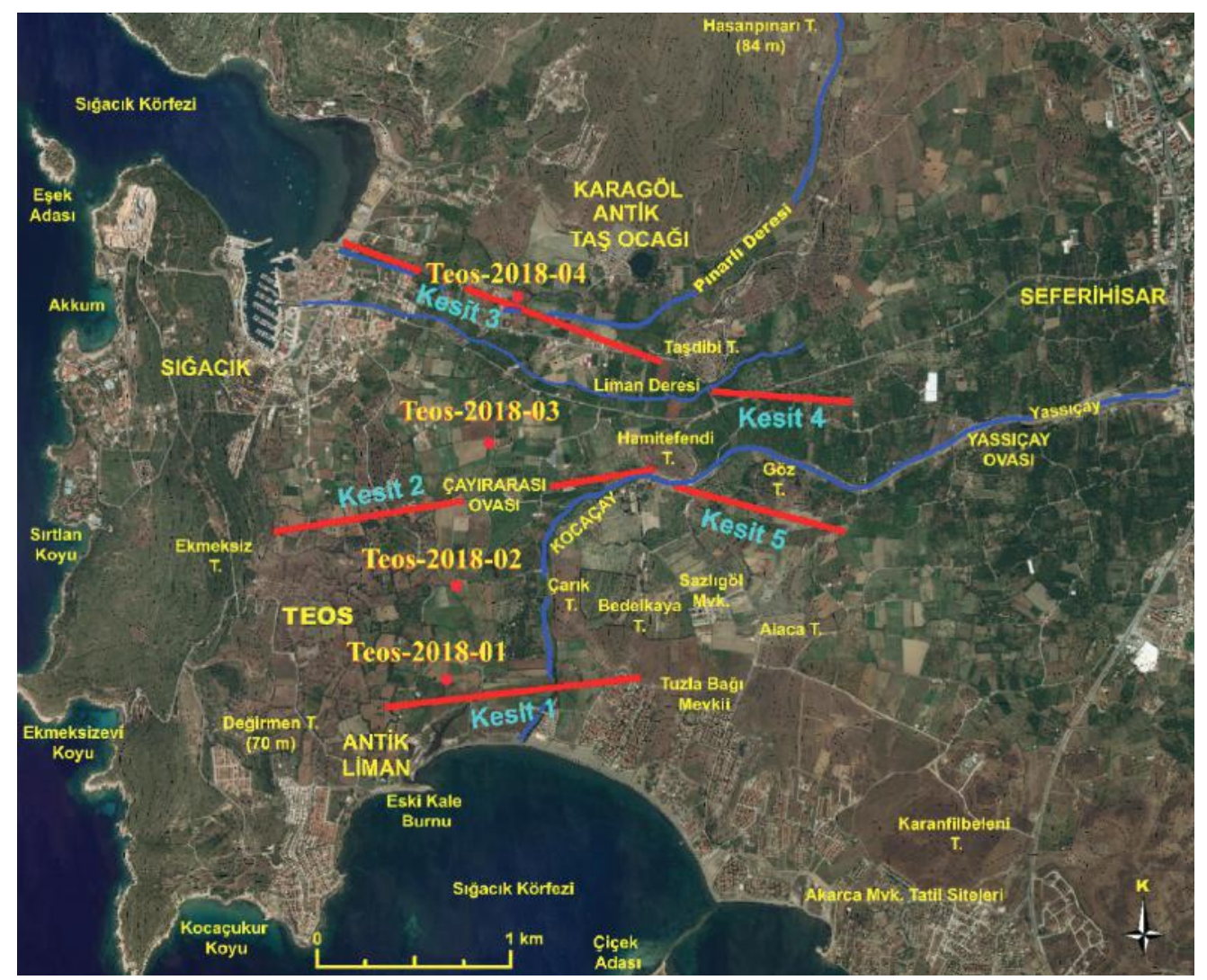

Şekil 9: Teos antik kenti çevresinde delgi sondaj çalışmalarının planlandığı hatlar.

Figure 9: Cross-section lines where drilling works are planned around the ancient city of Teos. 
önemlidir. Özellikle Teos yerleşimi yakın çevresi üzerine çok sayıda bilimsel soru bulunmakta olup bunlar yıllarca sürecek çalışmalarla yanıtlanabilecektir. Bu çalışmalar başlıca üç başlıkta toplanmaktadır. Ekmeksiz ve Hamitefendi tepeler arasında enine Holosen paleocoğrafyası kesitin (Kesit 2) hazırlanması için delgi sondajlar yapılması (Şekil 9). Taşdibi tepeden Sığacık kıyısına doğru bir hat üzerinde Holosen paleocoğrafya kesitinin (Kesit 3) hazırlanması için delgi sondajlar yapılması (Şekil 9). Taşdibi, Hamitefedi ve Çarık tepeler doğusuna doğru delgi sondajlar yapılarak Holosen transgresyonu ile denizin Yassıçay ovasına ne kadar sokulduğunun belirlenmesi (Kesit 4 ve 5) (Şekil 9). Bu çalışmalar, 2020 sondajları içinde planlanmış olup, yeni sondajlarda özellikle element analizlerinden yararlanarak paleosolller, eski arkeolojik katmanların doğal sedimanlar içindeki detaylı konumları değerlendirilecektir.

Teşekkür: Teos antik kenti çevresinde gerçekleştirdiğimiz sondaj çalışmalarına destekleri, kazı ve proje kapsamındaki katkıları için Teos kazısı başkanı Prof. Dr. Musa Kadıŏglu'na, kazı ekibine, kazı sponsorlarına (Kültür ve Turizm Bakanlığı, Kültür Varlıkları ve Müzeler Genel Müdürlüğü, Ankara Üniversitesi Dil ve Tarih Coğrafya Fakültesi, İzmir Valiliği, İzmir Büyükşsehir Belediyesi, Seferihisar Belediyesi, Türk Tarih Kurumu, Türkiye İş bankası, Yaşar Holding, Hiddenbay Teos) ve özellikle sondajlarda özveri ile çalışan öğrencilerimiz Dilan Demirel ve Cansel Dilşat Köse'ye teşekkür ederiz.

Hakem Değerlendirmesi: Dış bağımsız.

Çıkar Çatışması: Yazarlar çıkar çatışması bildirmemiştir.

Finansal Destek: Yazarlar bu çalışma için finansal destek almadığını beyan etmiştir.

Acknowledgement: We would like to thank Teos excavation head Prof. Dr. Musa Kadıoğlu, excavation team, excavation sponsors (Republic Of Turkey Ministry Of Culture and Tourism, General Directorate for Cultural Heritage and Museums, Ankara University Faculty Of Languages, History and Geography, Izmir Governorship, Izmir Metropolitan Municipality, Seferihisar Municipality, Turkish Historical Society, Türkiye İş Bankası, Yaşar Holding, Hiddenbay Teos) and especially our students Dilan Demirel and Cansel Dilşat Köse, who have worked devotedly in drilling, for their support for the drilling works we have carried out around the ancient city of Teos, and their contributions within the scope of the project. Conflict of Interest: The authors have no conflict of interest to declare.

Grand Support: The authors declared that this study has received no financial support.

\section{KAYNAKÇA/REFERENCES}

Adak, M. ve Kadığlu, M. (2017). Teos mermer ocakları ve Lucullus Mermeri. Philia, 3, 1-43.

Akartuna, M. (1962). İzmir-Torbal1-Seferihisar-Urla bölgesi'nin jeolojisi hakkında. MTA Dergisi.59, 1-19.

Altun, N. (2006-2008). Urla-Seferihisar (Izmir) bölgesinin jeolojisi ve toprak özellikleri. (Uzmanlık Tezi). T.C. Çevre ve Orman Bakanlı̆̆ı, Ege Ormancılık Araştırma Müdürlügü, İzmir.

Bakak, Ö. (2016). 2005 Sığacık Körfezi (İzmir) depremlerinin mekânsal değerlendirilmesi. Yerbilimleri, 37 (1), 51-63.

Brückner, H., Stock, F. \& Rauhut, R. (2013). Paläogeographische Forschungen in Teos, Rapor.

Butzer, K.W. (1982). Archaeology as human ecology. New York: Cambridge University Press.
Denizlioğlu, Z.A., Özmen, Ö. T., Kuru, T., Çolakoğlu, Z., Apak, A., Karaca, Ş., Şahin, C., Yaşar, A., Tengilimoğlu, E. (2006). 17-20 Ekim 2005, Urla- Sığacık Körfezi depremleri kuvvetli yer hareketi ivme kayıtları özelliklerinin incelenmesi. Afet İşleri Genel Müdürlüğü Deprem Araştırma Merkezi teknik raporu, Ankara.

Dewey, J. ve Şengör, A.M.C. (1979). Dewey J, Şengor AMC (1979). Aegean and surrounding regions: Complex multiplate and continuum tectonics in a convergent zone. Geological Society of America Bulletin, 90, 84-92.

Dunn, S.E. (2002). The chronology of the Aegean late bronze age with special reference to the Minoan eruption of Thera. Doctoral dissertation, University of Durham, Durham). Available at Durham E-Theses.

Düvenci, Y.R. (2013). Bağlararası'nda Santorini külleri (Çeşme Bağlararası'nda 4600 y1l öncesine ait tarihi kalıntılar). Bütün Dünya 2000, 16 (185), 55-58.

Eastwood, W.J., Pearce, N.J.G., Westgate, J. A. \& Perkins, W. T. 1998. Recognition of Santorini (Minoan) Tephra in Lake Sediments from Gölhisar Gölü, Southwest Turkey by Laser Ablation ICP-MS. JAS, 25, 677-687.

Eastwood, W.J., Pearce, N. J. G., Westgate, J. A., Perkins, W. T., Lamb, H.F. \& Roberts, N. 1999. Geochemistry of Santorini tephra in lake sediments from Southwest Turkey. Global and Planetary Change, 21, 17-29.

Eastwood, W.J., Tibby, J., Roberts, N., Birks, H.J.B. \& Lamb, H.F. 2002. The environmental impact of the Minoan eruption of Santorini (Thera): statistical analysis of palaeoecological data from Gölhisar, southwest Turkey. The Holocene, 12 (4), 431-444.

Emre, Ö., Özalp, S., Doğan, A., Özaksoy, V., Yıldırım, C. ve Göktaş, F., (2005): İzmir yakın çevresinin diri fayları ve deprem potansiyelleri. MTA Rapor No: 10754.

Erdoğan, B. (1990). İzmir-Ankara zonu ile Karaburun kuşağının tektonik ilişkisi. MTA Dergisi.110, 1-15.

Erdoğan, B., Altıner, D., Güngör, T. ve Özer, S. (1990). Karaburun Yarımadası'nın stratigrafisi. MTA Dergisi. 111, 1-23.

Erinç, S. (1965). Yağlş müessiriyeti üzerine bir deneme ve yeni bir indis. İstanbul Üniversitesi Edebiyat Fakültesi Coğrafya Enstitüsü Yayınları No: 41. İstanbul.

Erlat, E. (2003). İmir'in hava tipleri klimatolojisi. Ege Üniversitesi Yayınları Edebiyat Fakültesi yayın No: 121. İzmir.

Erol, O. (1983). Türkiye'nin Genç Tektonik ve Jeomorfolojik gelişimi. Jeomorfoloji Dergisi, 11, 1-22.

Er, Ö. (2011). İmir Seferihisar (Batı Türkiye) Africano mermerlerinin jeolojisi malzeme özellikleri ve durabilitesinin incelenmesi. (Yüksek Lisans Tezi). Dokuz Eylül Üniversitesi Fen Bilimleri Enstitüsü, İzmir.

Friedrich, W. L. (2000). Fire in the Sea, The Santorini Volcano: natural history and the legend of Atlantis. London: Cambridge University Press.

Friedrich, W.L., Kromer, B., Friedrich, M., Heinemeier, J., Pfeiffer, T. \& Talamo, S. (2006). Santorini eruption radiocarbon dated to $1627-$ 1600 B.C. Science, 312, 548. https://doi.org/10.1126/science.1125087 
Friedrich, W. L., Heinemeier, J. (2009). The Minoan eruption of Santorini radiocarbon dated to $1613 \pm 13 \mathrm{BC}$ - geological and stratigraphic considerations. 57-63. Time's Up! Dating the Minoan Eruption of Santorini, Monographs of the Danish Institute at Athens Volume 10, Editor: Hallager, E., Athens: Aarhus University Press.

Friedrich, W.L. (2013). The Minoan Eruption of Santorini around 1613 B.C. and its consequences", Tagungen des Landesmuseums für Vorgeschichte Halle, 9, 37-48.

Göktaş, F. (2014). Karaburun (İzmir) çevresinin Neojen stratigrafisi ve paleocoğrafik evrimi. MTA Dergisi 149, 71-94.

Günal. N. (1986). Gediz ve Büyük Menderes arasındaki sahanın bitki coğrafyası. (Doktora Tezi). İstanbul Üniversitesi Deniz Bilimleri ve Coğrafya Enstitüsü, İstanbul.

Kadıoğlu, M., Adak, M , Özbil, C., Yalçın, D.Ö. ve Polat, Y. (2012). 2010 Y1lı Teos Kazı Raporu (İlk Sezon). KST 33.3, 2011, 429-460.

Kadıoğlu, M. ve Özbil, C. (2015). Yeni araştırmalar 1şı̆̆ında Teos. Türk Eskiçă̆ Bilimleri Enstitüsü Haberler Dergisi, 40, 4-16.

Kadıoğlu M., (2016). der GeBraucH von marmorSorten in der arcHiteKtur von nYSa und teoS, Ancient Quarries And Building Sites In Asia Minor, 723-84, Bari.

Kayan, İ. (1988). Late Holocene sea-level changes on the Western Anatolian coast. Palaeogeography, Palaeoclimatology, Palaeoecology 68, (2-4), 205-218. https://doi.org/10.1016/0031-0182(88)90040-5

Kayan, İ. (1996). Holocene coastal development and archaeology in Turkey. Zeitschrift für Geomorphology. Supplementb and 102. Field Methods and Models to Quantify Rapid Coastal Changes. In D.H. Kelletat \& N.P. Psuty (Eds.). p. 37-59. Berlin. Germany. International Geographical Union. Commission on Coastal Systems. Proceedings of the Field Symposium Crete, Greece, April 1994.

Kayan, İ. (1998). Yeni yaklaşımlarla Türkiye'nin Plio-Kuaterner paleocoğrafyası. "21. Yüzyıla doğru Türkiye” Sempozyumu 1996, Bildiriler Kitabı. 189-197, Ankara.

Kayan, İ. (2000). İzmir çevresinin morfotektonik birimleri ve alüvyal jeomorfolojisi. Batı Anadolu'nun Depremselliği Sempozyumu: BADSEM 2000, Bildiriler Kitabı, 103-111, İzmir.

Kayan, İ. ve Öner, E. (2013). Bayraklı Höyüğü (İzmir) çevresinin Holosen'deki jeomorfolojik gelişimi. E. Öner (Ed.), Profesör Doktor Asaf Koçman'a Armă̆an kitabı içinde. (135-158). İzmir: Ege Üniversitesi Basımevi.

Koçman, A. (1993). Türkiye İklimi. Ege Üniversitesi Yayınları Edebiyat Fakültesi yayın No: 72. İzmir.

Kun, N. ve Türkmen, F. (2001). Teos yeşil mermerlerinin jeolojik konumu ve özellikleri. Türkiye III. Mermer Sempozyumu 2001, Bildiriler Kitabı. 1-7. Afyon.

Manning, S. (1988). The Bronze Age eruption of Thera: absolute dating, Aegean chronology and Mediterranean cultural interrelations. Journal of Mediterranean Archaeology, 1 (1), 17-82. https://doi. org/10.1558/jmea.v1i1.17

Manning, S.W, Ramsey, C.B., Kutschera, W., Higham. T., Kromer, B., Steier, P. \& Wild, E.M. 2006. Chronology for the Aegean Late Bronze Age 1700-1400 B.C.. Science, 312: 565-569. https://doi. org/10.1558/jmea.v1i1.1710.1126/science.1125682
Mater, B. (1982). Urla Yarımadasında arazinin sinıflandırılmast ile kullanılışı arasındaki ilişkiler. İstanbul Üniversitesi Edebiyat Fakültesi Yayınları No: 2863. İstanbul.

Meriç E., Avşar N. \& Bergin F. (2004). Benthic foraminifera of Eastern Aegean Sea (Turkey) systematics and autoecology. İstanbul: Turkish Marine Foundation. Publication no:18.

Meriç, E., Barut, İ. F., Nazik, A., Avşar, N., Yokeş, M. B., Eryılmaz, M., Eryılmaz, F.Y., Kam E., Sonuvar, B. ve Dinçer, F. (2018). Doğanbey Burnu (Seferihisar-İzmir) denizdibi termalsu kaynaklarının foraminifer, ostrakod ve mollusk topluluğuna etkisi. MTA Dergisi 156, 89-118.

Ocakoğlu, N., Demirbağ, E. \& Kuşçu, İ. (2004). Neotectonic structures in the area offshore of Alaçatı, Doğanbey and Kuşadası (western Turkey): evidence of strike-slip faulting in the Aegean extensional province. Tectonophysics, 391, 67-83. https://doi.org/10.1016/j.tecto.2004.07.008

Ocakoğlu, N. ve Demirbağ, E. (2005). İzmir Körfezi ve dolaylarının aktif tektonizmasının sismik yansıma verileri ile incelenmesi. ITÜ Dergisi, 4 (6), 93-104.

Omaç, F. (2014). Çeşme kazısında bugüne kadar bilinmeyen bir volkan patlamasının külleri ortaya çıktı. Çeşme Aktüel, 73, 24-27.

Öner, E. (1997a). Eşen Çayı taşkın - delta ovasının jeomorfolojisi ve antik Patara Limanı. Ege Coğrafya Dergisi 9, 89-130.

Öner, E. (1997b). Eşen Ovasının alüvyal jeomorfolojisi ve Likya antik kentleri. A.Ü.Türkiye Coğrafyası Araştırma ve Uygulama Merkezi Dergisi 6, 203-242. Ankara.

Öner, E. (1999). Letoon ve çevresinde paleo-jeomorfolojik araştırmalar. Ege Coğrafya Dergisi 10, 51-82.

Öner, E., (2013). Likya'da Paleocoğrafya ve Jeoarkeoloji Araştırmaları. Ege Üniversitesi Yayınları Edebiyat Fakültesi yayın No: 182. İzmir.

Öner, E. ve Kayan, İ. (2006). İzmir Körfezi kıyılarında alüvyon birikimi ile Karşıyaka ve Bayraklı kıyılarının şekillenmesi. Karşıyaka Kültür ve Çevre Sempozyumu, Bildiri Kitabı, 8 - 22, İzmir.

Öner, E., Doğan, M., İlhan, R., Yaman, F. ve Kayan, İ. (2018). KlazomenaiLimantepe çevresinde (Urla, İzmir) paleocoğrafya-jeoarkeoloji araştırmaları'. Kültür ve Truzim Bakanlığı, Kültür Varlıkları ve Müzeler Genel Müdürlüğü, 39. Uluslararası Kazı, Araştırma ve Arkeometri Sempozyumu-Bursa. 22-26 Mayıs 2017. 33. Arkeometri Sonuçları Toplantısı, 1. Cilt, s. 319-338, T.C. Kültür ve Turizm Bakanlığı Ana Yayın No: 3553/1, Kültür Varlıkları ve Müzeler Genel Müdürlüğü Yayın No: 180/1, ISSN: 1017-7671, Bursa.

Öner, E. ve Vardar, S. (2018). Santorini Tephra bulgular1 ve mikropaleontolojik analizler 1şığında Çeşme Bağlararası (İzmir) Tunç Çă̆ jeoarkeolojisi. Jeomorfoloji Derneği Bülteni, 2, 21-31

Ramsey, C.B., Manning, S.W. \& Galimberti, M. (2004). Dating the volcanic eruption at Thera. Radiocarbon, 46 (1), 325-344. https:// doi.org/10.1017/S0033822200039631

Sözbilir, H., Sümer Ö., Uzel, B., Ersoy, Y., Erkül, F., İnci, U., Helvac1, C. ve Özkaymak Ç. (2009). 17-20 Ekim 2005-Sığacık Körfezi (İzmir) depremlerinin sismik jeomorfolojisi ve bölgedeki gerilme alanları ile ilişkisi, Batı Anadolu. Türkiye Jeoloji Bülteni 52 (2), 217-238. 
Strabon, (2000). Antik Anadolu Coğrafyası (XII, XIII, XIV), (Çeviren: Adnan Pekman), Arkeoloji ve Sanat Yayınları, İstanbul.

Sullivan, D.G. (1988). The Discovery of Santorini Minoan Tephra in WesternTurkey.Nature,333,552-554.https://doi.org/10.1038/333552a0

Sullivan, D.G. (1990). Minoan tephra in lake sediments in Western Turkey, dating the eruption and assessing the atmospheric dispersal of the ash. In Thera and the Aegean World III, Volume Three: Chronology. Proceedings of the Third International Congress, Santorini, Greece". Thera Foundation, London, 114-119.

Şahoğlu V., Böyükulusoy, Ü.Ç., Erbil, Y.H., Erkanal, H. ve Tuğcu, İ. (2014). 2012 yılı Çeşme -Bağlararası kazıları, Anatolia 40, 179198.

Şengör, A.M.C., 1980. Türkiye'nin neotektoniğinin esasları. Türkiye Jeoloji Kurumu yayını, $40 \mathrm{~s}$.

Teos Kent Tarihi (2020, 21 Mayıs). Erişim adresi: http://www. teosarkeoloji.com//kent-tarihi

Teos Araştırma Tarihi (2020, 21 Mayıs). Erişim adresi: http://www. teosarkeoloji.com//arastirma-tarihi

Weiner, S. (2010). Human interactions with the Geosphere Microarchaeology, Beyond the visible archaeological record. Cambridge: Cambridge University Press The Edinburgh Building.

Vardar, S. ve Altıner, A. (2003). Gölcük Gölü’nün (İzmir/Ödemiş) jeomorfolojisi (Bir tephra kronolojisi örneği). CBÜ Sosyal Bilimler Dergisi, 1 (2), 93-104.

Vardar, S. (2010). Madra Çayı Deltası'nın Holosen kıyı paleo coğrafyasının değerlendirilmesinde foraminifer ve ostracod (Crustacea)'ların bir ortam belirleme indikatörü olarak kullanımı. TUCAUM VI. Ulusal Coğrafya Sempozyumu 2010, Bildiri Kitabı. 263-273, Ankara. Erişim adresi: http://tucaum.ankara.edu.tr/wpcontent/uploads/sites/280/2015/08/semp6_29.pdf
Vardar S. ve Öner, E. (2016). Bat1 ve Güneybatı Anadolu'nun paleocoğrafyası ve jeoarkeolojisinde Santorini (Thera) küllerinin önemi. A.Ü. Türkiye Coğrafyası Araştırma ve Uygulama Merkezi Coğrafi Bilimler Dergisi, 14 (1). 15-37.

Vardar, S. ve Öner, E. (2017). Batı Anadolu'da yeni Santorini Tephra bulguları ve paleocoğrafya-jeoarkeoloji dğerlendirmelerindeki önemi. Türk Coğrafya Kurumu 75. Yılı Uluslararası Sempozyumu 2017, Bildiriler Kitabı. 620-621, Ankara. Erişim adresi: http://www. tck.org.tr/75.Yil.Bildiriler.pdf

Vardar, S. (2018a). Sedimantolojik ve mikropaleontolojik verilerle Güzelhisar Çayı kıyı ovasının Holosen paleocoğrafyası. Doğu Coğrafya Dergisi, 39, 131-148.

Vardar, S. (2018b). Marmara Gölü'nün paleocoğrafyası ve Tunç Çă̆ı'ndan günümüze jeoarkeolojik değerlendirmeler, Manisa. Coğrafi Bilimler Dergisi, 16 (2), 217- 236.

Vespa, M., Keller, J. \& Gertisser, R. (2006). Interplinian explosive activity of Santorini volcano (Greece) during the past 150,000 years. Journal of Volcanology and Geothermal Research 153, 206286. https://doi.org/10.1016/j.jvolgeores.2005.12.009

Yaman, F. (2018). Urla Kıyı düzlüğünün paleocoğrafyası ve LimantepeKlazomenai (Urla-İzmir) arkeolojisi üzerine sedimantolojikpaleontolojik Katkılar. (Yüksek Lisans Tezi). Ege Üniversitesi Sosyal Bilimler Enstitüsü, İzmir.

Yiğitbaşığlu, H. (2003). Santorini Volkanı ve Minoan püskürmesinin Türkiye'deki izleri. Coğrafi Bilimler Dergisi, 1 (1), 69-74. 